This document is the accepted manuscript version of the following article:

Winnefeld, F., Epifania, E., Montagnaro, F., \& Gartner, E. M. (2019). Further studies of the hydration of Mgo-hydromagnesite blends. Cement and Concrete Research, 126, 105912

(12 pp.). https://doi.org/10.1016/j.cemconres.2019.105912

This manuscript version is made available under the CC-BY-NC-ND 4.0

1icense http://creativecommons.org/1icenses/by-nc-nd/4.0/

\title{
1 Further studies of the hydration of MgO-hydromagnesite blends
}

2

3 Frank Winnefeld ${ }^{\mathrm{a}}$, Eugenia Epifania ${ }^{\mathrm{a}, \mathrm{b}}$, Fabio Montagnaro ${ }^{\mathrm{b}}$, Ellis M. Gartner ${ }^{\mathrm{c}, *}$

6 Concrete and Construction Chemistry, CH-8600 Dübendorf, Switzerland

$7 \quad{ }^{\mathrm{b}}$ Dipartimento di Scienze Chimiche, Università degli Studi di Napoli Federico II, Complesso

8 Universitario di Monte Sant'Angelo, 80126 Naples, Italy

$9{ }^{\mathrm{c}}$ Department of Civil and Environmental Engineering, Imperial College London,

10 South Kensington Campus, London SW7 2AZ, United Kingdom

$11 *$ Deceased as of February 13, 2018

\section{ABSTRACT}

The hydration of magnesium oxide in the presence of hydromagnesite $\left(\mathrm{Mg}_{5}\left(\mathrm{CO}_{3}\right)_{4}(\mathrm{OH})_{2} \cdot 4 \mathrm{H}_{2} \mathrm{O}\right)$ was investigated. The hydration products are a poorly-crystalline form of brucite $\left(\mathrm{Mg}(\mathrm{OH})_{2}\right)$ and an unknown amorphous or poorly crystalline hydrate, which was evidenced by X-ray diffraction analyses and Raman spectroscopy. By thermogravimetry it was found that in the presence of hydromagnesite more water is bound in hydrate phases than can be explained by the formation of brucite only. The unknown hydrate is hypothesized to lead to cohesive binding in $\mathrm{MgO}$-hydromagnesite blends. Due to thermodynamic

21 predictions artinite $\left(\mathrm{Mg}_{2}\left(\mathrm{CO}_{3}\right)(\mathrm{OH})_{2} \cdot 3 \mathrm{H}_{2} \mathrm{O}\right)$ should be the stable hydrate in this system. The addition artinite crystal seeds, however, had no significant effect on hydration kinetics or nature of the reaction products. The hypothesis that the addition of sodium bicarbonate supply of additional $\mathrm{HCO}_{3}{ }^{-}$ions was also not supported by the experiments. 
Keywords: magnesium oxide, cement, hydration, hydromagnesite, artinite, dypingite, brucite

\section{Introduction}

Enormous volumes of concrete and other cement-based materials are used globally, essentially all based on hydraulic binders in which Portland Cement Clinker (PCC), comprising highly basic calcium silicates and aluminates, is the primary active component. Because even mildly basic calcium silicates and aluminates do not occur in significant quantities at the surface of the Earth, the manufacture of PCC requires calcium carbonate, readily available globally as limestone, as the calcium source and main raw material. As the limestone is decarbonated in the process, manufacture of PCC has a high carbon footprint, more than $50 \%$ of which represents "fossil" $\mathrm{CO}_{2}$ released from the limestone raw material. The decarbonation of limestone is also strongly endothermic and thus requires significant thermal energy, generally derived by the combustion of carbon-rich fuels, which accounts for most of the rest of the manufacturing $\mathrm{CO}_{2}$ emissions. It is estimated that specific $\mathrm{CO}_{2}$ emissions for manufacture of PCC globally average $866 \mathrm{~kg} / \mathrm{t}$ [1]. In practice, PCC is usually diluted to a significant extent with other ingredients (calcium sulfates, fillers, and "supplementary cementitious materials") which generally have much lower specific carbon footprints, leading to a global average specific $\mathrm{CO}_{2}$ footprint of $660 \mathrm{~kg} / \mathrm{t}$ for all PCC-based hydraulic binders [1]. Because of this, and the fact that such hydraulic binders are currently used in vast quantities (4.6 Gt in 2015) [2], cement manufacture may now represent as much as $8 \%$ of global anthropogenic $\mathrm{CO}_{2}$ emissions [3, 4]. The average $\mathrm{CO}_{2}$ footprint of PCC-based cements can still be reduced further than this by additional clinker dilution, but seems unlikely to ever fall much below about $500 \mathrm{~kg} / \mathrm{t}$ assuming a realistic target of the clinker factor of approximately $60 \%[5]$. 
Because of this, the search continues for practical alternative active binder components, which we refer to as "alternative clinkers," that can potentially replace PCC with a product of much lower carbon footprint in a significant fraction of its applications [6-10]. But most of the alternative clinkers that have been proposed are still based on calcium silicates and aluminates, which greatly limit the extent of the $\mathrm{CO}_{2}$ reductions that can be achieved in theory, because the main calcium source is always limestone, even though the amounts required may be somewhat less than for PCC.

It is easy to make hydraulic binders from basic calcium silicates and aluminates because of their inherently high hydraulic reactivity. But the possibility also exists of making hydraulic binders from basic magnesium compounds, and in this case the potential raw materials are very different. Generally reactive $\mathrm{MgO}$ is used as raw material, which is mostly produced by the calcination of magnesite $\left(\mathrm{MgCO}_{3}\right)$ at significantly lower temperatures compared to Portland cement clinker [11]. The production of $\mathrm{MgO}$ from magnesite, however, releases approximately $1100 \mathrm{~kg} \mathrm{CO}_{2}$ per $\mathrm{kg} \mathrm{MgO}[10,12]$, which is significantly higher than for Portland cement. $\mathrm{MgO}$ can be used to make a variety of hydraulic binders as well as binders that harden by carbonation $[11,13]$. Good progress has been made in recent years in understanding $\mathrm{MgO}$-based binders that harden by carbonation, which are able to sequestrate a reasonable amount of $\mathrm{CO}_{2}$, thus greatly improving the $\mathrm{CO}_{2}$ balance of such binders [14-25]. Magnesium sources are at the Earth's surface not only available as carbonates, but also in the form of highly basic silicate rocks which contain very little, if any, fossil $\mathrm{CO}_{2}$ [26]. The two main mineral types of interest are (i) olivines close in composition to forsterite $\left(\mathrm{Mg}_{2} \mathrm{SiO}_{4}\right)$, which are anhydrous minerals of igneous origin and have the highest $\mathrm{MgO}$ content of any common mineral, and (ii) serpentines $\left(\mathrm{Mg}_{3} \mathrm{Si}_{2} \mathrm{O}_{5}(\mathrm{OH})_{4}\right)$, which are more abundant and produced by partial hydration of olivines near the Earth's surface. Basic magnesium silicate minerals react only very slowly with water and $\mathrm{CO}_{2}$ at the Earth's surface, which is why they 
are readily available. Therefore, the challenge is to find energy-efficient ways to activate them such that they can be used to make hydraulic binders that hydrate at high enough rates for use in construction applications $[8,10]$. Small amounts of brucite $\left(\mathrm{Mg}(\mathrm{OH})_{2}\right)$ can also sometimes be found associated with serpentine, but not in sufficient quantity for the uses considered here, so in this sense brucite cannot be considered to be a "common" mineral.

The theoretical enthalpy requirement for decomposing forsterite into $\mathrm{MgO}$ (periclase) and $\mathrm{SiO}_{2}$ (quartz) is only about $0.86 \mathrm{~kJ}$ per gram of $\mathrm{MgO}$ [10]. This compares very favourably with the enthalpy requirement of $2.90 \mathrm{~kJ}$ per gram of $\mathrm{MgO}$ for the conventional industrial manufacturing process of $\mathrm{MgO}$ by thermally decomposing natural magnesite $\left(\mathrm{MgCO}_{3}\right)$ into $\mathrm{MgO}$ plus gaseous $\mathrm{CO}_{2}$ [10]. Additionally, the use of forsterite as the raw material releases no fossil $\mathrm{CO}_{2}$, whereas the use of magnesite releases $1.1 \mathrm{~g}$ of fossil $\mathrm{CO}_{2}$ for each $\mathrm{g}$ of $\mathrm{MgO}$ produced [10]. It would therefore be very advantageous if $\mathrm{MgO}$ could be manufactured efficiently by decomposition of forsterite-rich olivines. Unfortunately, no energy-efficient industrial process for this currently exists as high temperatures and high partial pressures of $\mathrm{CO}_{2}$ are required [27-32]; but it is possible that such processes will be developed if they were made the subject of intensive research. Some recent progress in this area was made by one of the authors [33]. The use of serpentinite as a raw material is also possible [34], although less favourable because of its significant bound water content. The heat of formation of serpentine (assumed $\mathrm{Mg}_{3} \mathrm{Si}_{2} \mathrm{O}_{5}(\mathrm{OH})_{4}$ ) from the oxides in their standard states is in the range of $-150 \ldots-180 \mathrm{~kJ} / \mathrm{mol}$ depending on the type of serpentine [35]. Taking the pessimistic value of $-180 \mathrm{~kJ} / \mathrm{mol}, 60 \mathrm{~kJ} / \mathrm{mol} \mathrm{MgO}$ result. If the enthalpy of evaporation of $2 / 3$ mole of water per mole of $\mathrm{MgO}$ is added, i.e. $44 \mathrm{~kJ} \cdot 2 / 3 \approx 30 \mathrm{~kJ}$, this gives $90 \mathrm{~kJ} / \mathrm{mol} \mathrm{MgO}$ or $2.25 \mathrm{~kJ} / \mathrm{g} \mathrm{MgO}$. This is still less than making $\mathrm{MgO}$ from magnesite. However, if this water must be evaporated, the energy cost will be high, but if the $\mathrm{MgO}$ could be extracted by a leaching process without water evaporation, more acceptable extraction energies may be feasible. Furthermore, Mg-containing brines might be potential sources of $\mathrm{MgO}$ [36-39]. 
105 Carbonation hardening is of potential interest for factory-made products, and has the added

106 advantage that it consumes large amounts of $\mathrm{CO}_{2}$ in the hardening process. But the potential

107 value of a hydraulic binder based on magnesium oxides and carbonates would be significantly

108 greater than a binder that can only be hardened by carbonation. There is a wider range of

109 potential applications for hydraulic binders because they do not need a concentrated source of

110 gaseous $\mathrm{CO}_{2}$, which is difficult to provide in many locations. In both cases, if the final

111 composition of the hardened binder were sufficiently rich in carbonate such that the $\mathrm{CO}_{2}$

112 sequestered by it could fully compensate for the $\mathrm{CO}_{2}$ emitted by the production of the energy

113 needed to drive the manufacturing process, we could talk of a truly carbon-neutral binder. We

114 could even envisage carbon-negative binders, for which there was net consumption of $\mathrm{CO}_{2}$

115 during manufacture and use. This was the original concept behind the "Novacem" start-up

116 venture [40], which was built on the discovery that reactive $\mathrm{MgO}$, when hydrated together

117 with certain magnesium carbonates, such as hydromagnesite, $\left(\mathrm{HY}, \mathrm{Mg}_{5}\left(\mathrm{CO}_{3}\right)_{4}(\mathrm{OH})_{2} \cdot 4 \mathrm{H}_{2} \mathrm{O}\right)$,

118 gave a relatively strong hydraulic binder, compared to $\mathrm{MgO}$ hydrated alone, which had almost

119 no binding capacity [41-46]. It was also observed that the brucite $\left(\mathrm{Mg}(\mathrm{OH})_{2}\right)$ formed in the

120 presence of hydromagnesite gave very broad X-ray diffraction reflections compared to that

121 formed from hydration of pure $\mathrm{MgO}$, and it was assumed that the strength of the hydration

122 products in these systems was related in some way to the form of the brucite precipitated.

124 A recent detailed study of the mechanisms involved in the hydration of this type of binder

125 [46] forms the starting point for the work reported in this paper. It was found that the addition

126 of hydromagnesite accelerates the hydration of reactive periclase and leads to a significant

127 development of compressive strength, while the brucite formed by the hydration of pure

128 periclase gives only very weak pastes. By thermodynamic calculations, artinite was predicted

129 to occur as stable phase in $\mathrm{MgO}$-hydromagnesite blends. However, the authors did not clearly

130 identify any new phase in the MgO-hydromagnesite blends besides the formation of a poorly 
crystalline brucite, and suggested that artinite formation is kinetically hindered. They hypothesized the formation of an amorphous phase intermediate between hydromagnesite and brucite, which could explain the strength development in MgO-hydromagnesite blends.

The current study was aimed at increasing the initial carbonate content of such binders in order to enhance their effectiveness as a means of reducing global $\mathrm{CO}_{2}$ emissions as less $\mathrm{MgO}$, whose production is associated with $\mathrm{CO}_{2}$ emissions, especially when it is produced from the calcination of magnesite, is used in the blend. It was also aimed at testing the concept that a new hydrate phase may be responsible for the strong hydraulic binding obtained by the addition of hydromagnesite to reactive $\mathrm{MgO}$ pastes. Two approaches were applied in this study:

1. Finely ground crystalline (natural) artinite was added as seed crystals to $\mathrm{MgO}-\mathrm{HY}$ mixtures to determine whether the crystallization of artinite could be promoted, as would be expected if it were the thermodynamically favoured product phase. If this approach were successful, the initial hydromagnesite contents of the binders could in theory be increased to about $80 \%$ based on the theoretical hydration reaction given in Eq. (1):

$$
3 \mathrm{MgO}+\mathrm{Mg}_{5}\left(\mathrm{CO}_{3}\right)_{4}(\mathrm{OH})_{2} \cdot 4 \mathrm{H}_{2} \mathrm{O}+11 \mathrm{H}_{2} \mathrm{O} \rightarrow 4 \mathrm{Mg}_{2}\left(\mathrm{CO}_{3}\right)(\mathrm{OH})_{2} \cdot 3 \mathrm{H}_{2} \mathrm{O}
$$

2. Sodium bicarbonate $\left(\mathrm{NaHCO}_{3}\right)$ was added to the mixing water to determine if it would modify or accelerate the hydration reactions. This salt was chosen because it is highly soluble and provides one ion $\left(\mathrm{HCO}_{3}{ }^{-}\right)$in common with magnesium carbonates in the mildly basic $\mathrm{pH}$ range, and it is observed that salt-based hydration accelerators often share a common ion with the hydrating phases [47]. However, it was observed by [48, 49] that $\mathrm{NaHCO}_{3}$ slightly reduced the dissolution kinetics of $\mathrm{MgO}$ without and with the addition of hydromagnesite seeds. The authors attributed this effect to the increase of the $\mathrm{pH}$ value in the presence of $\mathrm{NaHCO}_{3}$. In addition, $\mathrm{NaHCO}_{3}$ has been shown to aid in the carbonation of basic magnesium compounds [33, 48, 49]. 
$158 \quad$ 2. Materials and Methods

\section{$159 \quad 2.1 \quad$ Materials}

160 Magnesium oxide (MgO) was prepared by igniting laboratory-grade brucite (Fisher Scientific,

$161 \mathrm{UK}$ ) in a furnace at $900^{\circ} \mathrm{C}$ for $6 \mathrm{~h}$, which yields a light-burned, high reactive $\mathrm{MgO}$ [19].

162 Laboratory grade hydromagnesite (HY, Alfa Aesar, Germany) and sodium hydrogen

163 carbonate $\left(\mathrm{NaHCO}_{3}\right.$, Honeywell, Germany) were used.

164 Artinite is not available from commercial suppliers of laboratory chemicals, and no synthesis

165 procedure is described in open literature. Thus a natural mineral originating from San Benito

166 County, California, USA (Fig. 1a), was purchased from Siber+Siber AG, Aathal, Switzerland.

167 From the sample, approximately $20 \mathrm{~g}$ artinite crystals were separated and gently ground by

168 hand in an agate mortar to a particle size below $63 \mu \mathrm{m}$.

169 Table 1 gives the chemical composition of the Mg-based raw materials as determined by X-

170 ray fluorescence analysis. The reactivity of the magnesium oxide was tested using the citric

171 acid method, where the time needed for $2.00 \mathrm{~g}$ of $\mathrm{MgO}$ to neutralize $100 \mathrm{~mL}$ of a $0.4 \mathrm{M}$ citric

172 acid solution is measured [50]. The sample showed a neutralization time of $145 \mathrm{~s}$ and thus

173 proved to be of medium reactivity (neutralization time between 180 and $300 \mathrm{~s}$ ).

174 The composition of the artinite sample is close to the theoretical composition of the pure

175 phase. Its XRD pattern (Fig. 1b) is similar to the ones contained in the ICSD database;

176 however some differences occur between all patterns, which might be related to different

177 sample preparation and XRD measuring techniques as well as to possible differences in the

178 composition of the various natural artinite samples.

179 
180 Table 1: Chemical composition and density of the used binder components.

\begin{tabular}{lccc}
\hline $\begin{array}{l}\text { Oxide } \\
\text { (mass-\%) }\end{array}$ & $\mathrm{MgO}$ & Hydromagnesite & Artinite \\
\hline $\mathrm{CaO}$ & 0.14 & 0.27 & 0.06 \\
$\mathrm{SiO}_{2}$ & $<0.05$ & $<0.05$ & 0.80 \\
$\mathrm{Al}_{2} \mathrm{O}_{3}$ & 0.06 & $<0.04$ & $<0.04$ \\
$\mathrm{Fe}_{2} \mathrm{O}_{3}$ & $<0.024$ & 0.03 & 0.08 \\
$\mathrm{MgO}$ & 99.27 & 42.56 & 42.01 \\
$\mathrm{~K}_{2} \mathrm{O}$ & $<0.02$ & $<0.02$ & $<0.02$ \\
$\mathrm{Na}_{2} \mathrm{O}$ & $<0.04$ & $<0.04$ & $<0.04$ \\
$\mathrm{TiO}_{2}$ & $<0.007$ & $<0.007$ & $<0.007$ \\
$\mathrm{P}_{2} \mathrm{O}_{5}$ & 0.006 & 0.026 & 0.006 \\
$\mathrm{Cr}_{2} \mathrm{O}_{3}$ & 0.004 & $<0.002$ & 0.003 \\
$\mathrm{MnO}$ & 0.004 & 0.006 & 0.003 \\
$\mathrm{SO}_{3}$ & 0.21 & 0.20 & 0.07 \\
$\mathrm{L.O}_{3} \mathrm{I}^{\mathrm{a}}$ & 0.32 & 56.91 & 56.93 \\
\hline Total & 100.00 & 100.00 & 99.96 \\
\hline $\mathrm{CO}_{2}(\mathrm{mass} \%)^{\mathrm{b}}$ & 0.70 & 38.50 & 22.32 \\
Density $\left(\mathrm{g} / \mathrm{cm}^{3}\right)^{\mathrm{c}}$ & 3.45 & 2.14 & n.d. \\
\hline
\end{tabular}

$181{ }^{\mathrm{a}}$ loss on ignition determined according to EN 196-2

$182{ }^{\mathrm{b}}$ combustion analysis

$183{ }^{\mathrm{c}}$ according to EN 196-6 (pycnometric method)

184 n.d.: not determined

185

186 

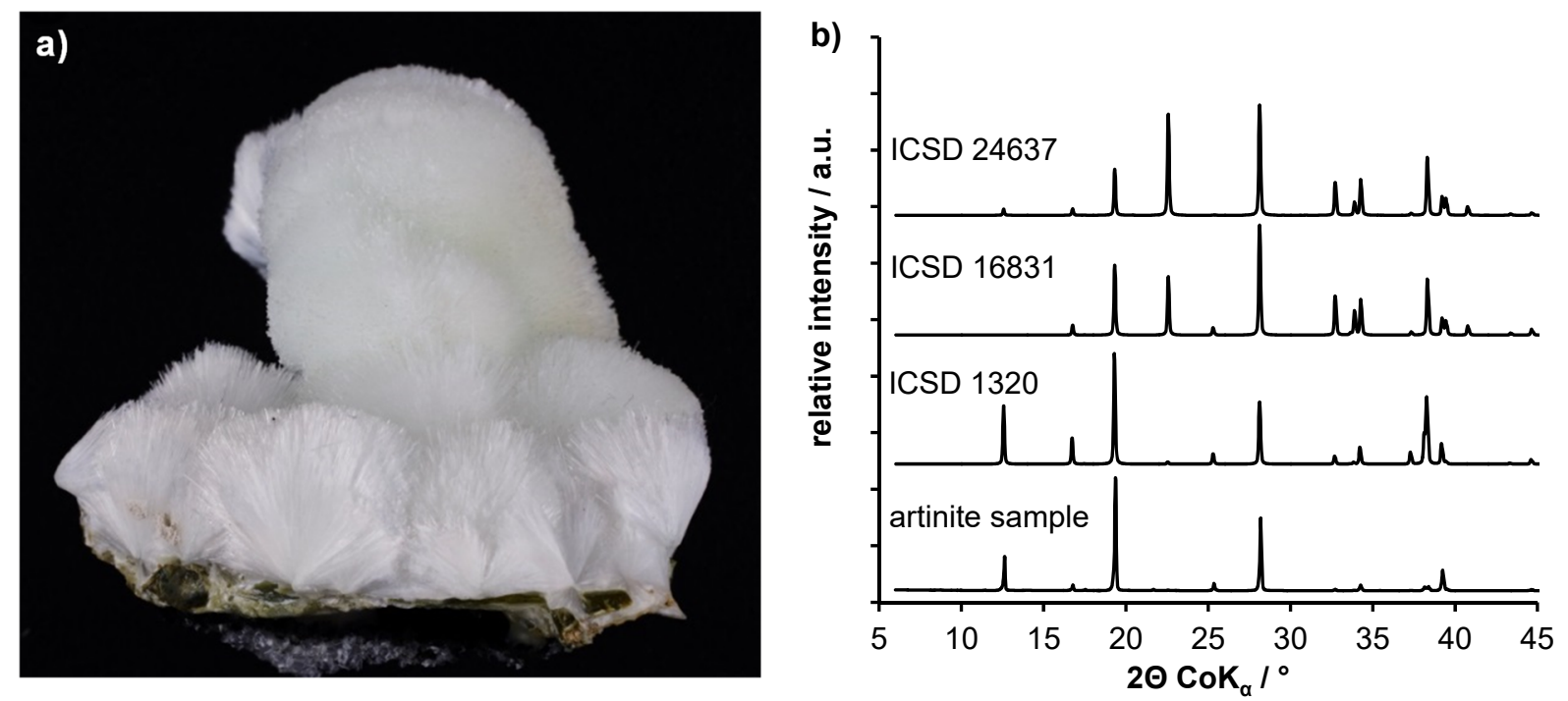

187 Fig. 1: (a) Artinite mineral used in the experiments. The diameter of the sample is

188 approximately $4 \mathrm{~cm}$. (b) Comparison of the XRD pattern of the artinite sample with reference patterns ICSD 1320 [51], ICSD 16831 [52] and ICSD 24637 [53].

192 The particle size distributions of the raw materials were analyzed using a laser particle

193 analyzer Malvern Mastersizer X. The powders were dispersed in isopropanol by ultrasound.

194 Fig. 2 shows the results. The laboratory chemicals (MgO, HY) show a finer particle size

195 distribution than the ground artinite. The particle size of $\mathrm{NaHCO}_{3}$ was not analyzed as it was

196 dissolved in the mixing water prior to use.

197 Table 2 shows the paste mix designs used in this study. A high water/solid ratio of 1.2 was 198 necessary to achieve workable pastes. 

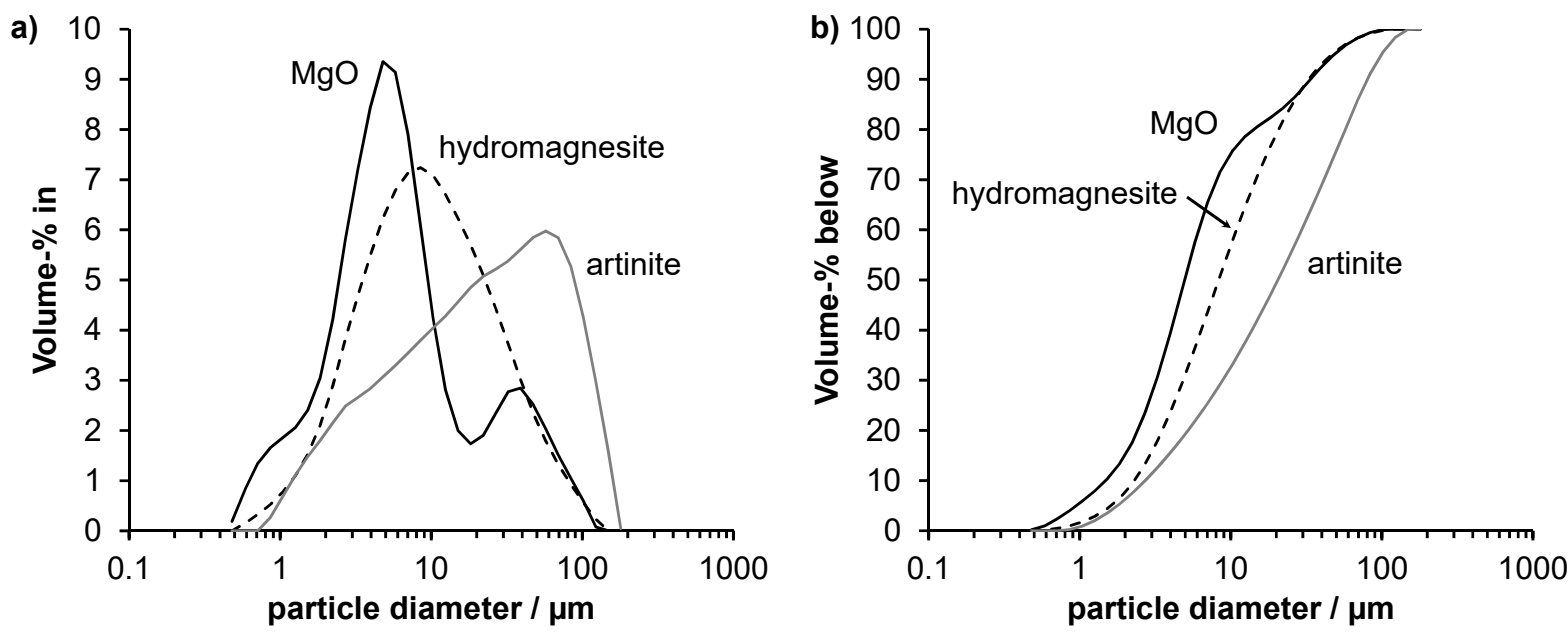

Fig. 2: Particle size distribution of the binder constituents. (a) differential particle size

201 distribution, (b) cumulative particle size distribution.

204 Table 2: Mix designs of the pastes used in this study referring to $100 \mathrm{~g}$ solid.

\begin{tabular}{ccccc}
\hline $\mathrm{MgO}$ & $\begin{array}{c}\text { Hydromagnesite } \\
(\mathrm{HY})\end{array}$ & $\begin{array}{c}\text { Artinite } \\
(\text { Art })\end{array}$ & $\mathrm{NaHCO}_{3}$ & Water \\
$\mathrm{g}$ & $\mathrm{g}$ & $\mathrm{g}$ & $\mathrm{g}$ & $\mathrm{g}$ \\
\hline 100 & - & - & - & 120 \\
70 & 30 & - & - & 120 \\
70 & 28 & 2 & - & 120 \\
70 & 28 & - & 2 & 120 \\
50 & 50 & - & - & 120 \\
\hline
\end{tabular}

205

\subsection{Methods}

\subsubsection{Thermodynamic modelling}

209 Thermodynamic modelling was used to calculate the thermodynamically stable phases in the system $\mathrm{MgO}-\mathrm{CO}_{2}-\mathrm{H}_{2} \mathrm{O}$ at ambient temperature and pressure. The geochemical GEMS-PSI

211 software [54, 55] was applied together with the Nagra/PSI database [56], the SLOP98 [57, 58]

212 database and additional data for lansfordite [59, 60] and nesquehonite [61]. Recently, the

213 solubility product of dypingite, $\mathrm{Mg}_{5}\left(\mathrm{CO}_{3}\right)_{4}(\mathrm{OH})_{2} \cdot 5 \mathrm{H}_{2} \mathrm{O}$, was determined as $\log \mathrm{K}^{\circ}=-34.94$ at 
$21423^{\circ} \mathrm{C}$ [62], which is several log units higher than for hydromagnesite, see [63] and references

215 cited therein, indicating that dypingite is expected to be less stable than hydromagnesite. The

$216 \log \mathrm{K}^{\circ}$ value was used together with values for $\mathrm{S}^{\circ}$ and $\mathrm{C}_{\mathrm{p}}{ }^{\circ}$ estimated according to [57] to

217 calculate $\Delta_{\mathrm{f}} \mathrm{G}^{\circ}$ and $\Delta_{\mathrm{f}} \mathrm{H}$ of dypingite using the Nagra/PSI thermodynamic data base [56].

218 Table 3 displays the thermodynamic data of the solid phases used in the calculations. The

219 theoretical phase assemblage of mixtures of $\mathrm{MgO}$ and hydromagnesite was calculated. The

220 formation of magnesite, which is predicted to form as the thermodynamically stable phase,

221 was suppressed as it is generally not identified in such systems [46, 63].

223 Table 3: Selected standard thermodynamic properties of the solid phases at $25^{\circ} \mathrm{C}$ and 1 bar

224 used in the calculations.

\begin{tabular}{lccccccc}
\hline Phase $\left.{ }^{1}\right)$ & $\left.\log \mathrm{K}^{\circ}{ }^{2}\right)$ & $\begin{array}{c}\Delta_{\mathrm{f}} \mathrm{G}^{\circ} \\
\mathrm{kJ} / \mathrm{mol}\end{array}$ & $\begin{array}{c}\Delta_{\mathrm{f}} \mathrm{H}^{\circ} \\
\mathrm{kJ} / \mathrm{mol}\end{array}$ & $\begin{array}{c}\mathrm{S}^{\circ} \\
\mathrm{J} /(\mathrm{mol} \cdot \mathrm{K})\end{array}$ & $\begin{array}{c}\mathrm{C}_{\mathrm{p}}^{\circ} \\
\mathrm{J} /(\mathrm{mol} \cdot \mathrm{K})\end{array}$ & $\begin{array}{c}\mathrm{V}_{\mathrm{m}} \\
\mathrm{cm}^{3} / \mathrm{mol}\end{array}$ & Ref. \\
\hline Periclase, $\mathrm{MgO}$ & & -569.38 & -601.66 & 26.95 & 37.8 & 11.25 & {$[57,58]$} \\
Brucite, $\mathrm{Mg}(\mathrm{OH})_{2}$ & -11.16 & -832.23 & -923.27 & 63.14 & 77.28 & 24.63 & {$[56]$} \\
Magnesite, $\mathrm{MgCO}_{3}$ & -8.29 & -1029.3 & -1112.9 & 65.69 & 75.85 & 28.02 & {$[56]$} \\
$\begin{array}{l}\text { Nesquehonite, } \\
\mathrm{MgCO}_{3} \cdot 3 \mathrm{H}_{2} \mathrm{O}\end{array}$ & -5.34 & -1724.0 & -1977.3 & 195.6 & $\left.237.8{ }^{3}\right)$ & 74.8 & {$[57,58$,} \\
$\begin{array}{l}\text { Lansfordite, } \\
\mathrm{MgCO}_{3} \cdot 5 \mathrm{H}_{2} \mathrm{O}\end{array}$ & -5.24 & -2197.8 & -2574.3 & 249.5 & $\left.317.9{ }^{4}\right)$ & 103.19 & {$[59,60]$} \\
$\mathrm{Hydromagnesite}_{2}$ & -38.47 & -5864.7 & -6504.1 & 541.3 & 571.3 & 208.8 & {$[57,58]$} \\
$\mathrm{Mg}_{5}\left(\mathrm{CO}_{3}\right)_{4}(\mathrm{OH})_{2} \cdot 4 \mathrm{H}_{2} \mathrm{O}$ & & & & & & & \\
Dypingite $\left.^{5}\right)$, & -34.94 & -6081.7 & -6777.4 & 585.9 & 611.3 & 225.9 & {$[62,64]$} \\
$\mathrm{Mg}_{5}\left(\mathrm{CO}_{3}\right)_{4}(\mathrm{OH})_{2} \cdot 5 \mathrm{H}_{2} \mathrm{O}$ & & & & & & & \\
$\mathrm{Artinite}$ & -18.67 & -2568.6 & -2920.6 & 232.9 & 296.1 & 96.9 & {$[57,58]$} \\
$\mathrm{Mg}_{2}\left(\mathrm{CO}_{3}\right)(\mathrm{OH})_{2} \cdot 3 \mathrm{H}_{2} \mathrm{O}$ & & & & & & & \\
\hline
\end{tabular}

$\left.{ }^{1}\right)$ Several other phases exist in the system $\mathrm{MgO}-\mathrm{CO}_{2}-\mathrm{H}_{2} \mathrm{O}$, namely barringtonite $\left(\mathrm{MgCO}_{3} \cdot 2 \mathrm{H}_{2} \mathrm{O}\right)$, pokrovskite $\left(\mathrm{Mg}_{2}\left(\mathrm{CO}_{3}\right)(\mathrm{OH})_{2}\right)$, giorgiosite $\left(\mathrm{Mg}_{5}\left(\mathrm{CO}_{3}\right)_{4}(\mathrm{OH})_{2} \cdot 5 \mathrm{H}_{2} \mathrm{O}\right)$, an unnamed dypingite-like phase $\left(\mathrm{Mg}_{5}\left(\mathrm{CO}_{3}\right)_{4}(\mathrm{OH})_{2} \cdot 8 \mathrm{H}_{2} \mathrm{O}\right)$, protohydromagnesite $\left(\mathrm{Mg}_{5}\left(\mathrm{CO}_{3}\right)_{4}(\mathrm{OH})_{2} \cdot 11 \mathrm{H}_{2} \mathrm{O}\right)$ and shelkovite $\left(\mathrm{Mg}_{7}\left(\mathrm{CO}_{3}\right)_{5}(\mathrm{OH})_{4} \cdot 24 \mathrm{H}_{2} \mathrm{O}\right)$ [65-68], where no thermodynamic data are available in open literature.

$\left.{ }^{2}\right) \log \mathrm{K}^{\circ}$ values refer to reactions formulated with $\mathrm{Mg}^{2+}, \mathrm{CO}_{3}^{2-}, \mathrm{OH}^{-}$and $\mathrm{H}_{2} \mathrm{O}$. They were calculated using the Nagra/PSI thermodynamic data base [56] except for dypingite, where the value taken from [62] is given.

$\left.{ }^{3}\right)$ The Slop98 database $[57,58]$ integrated in GEMS gives for nesquehonite a negative value of $\mathrm{C}_{\mathrm{p}}{ }^{\circ}$. The original value taken from [61] was used instead.

$\left.{ }^{4}\right)$ For lansfordite, [59] gives a $\mathrm{C}_{\mathrm{p}}{ }^{\circ}$ of $386 \mathrm{~J} /(\mathrm{mol} \cdot \mathrm{K})$, which deviates strongly from the value of $\mathrm{S}^{\circ}$ and thus does not seem to be trustworthy. Therefore $\mathrm{C}_{\mathrm{p}}{ }^{\circ}$ was estimated according to Helgeson et al. [57] using $\mathrm{C}_{\mathrm{p}}{ }^{\circ}$ of nesquehonite and of structural water $(40.04 \mathrm{~J} /(\mathrm{mol} \cdot \mathrm{K}))$.

$\left.{ }^{5}\right) \mathrm{S}^{\circ}$ and $\mathrm{C}_{\mathrm{p}}{ }^{\circ}$ were estimated according to [57] from the respective values of hydromagnesite and structural water $\left(\mathrm{S}^{\circ}=40.17 \mathrm{~J} /(\mathrm{mol} \cdot \mathrm{K}), \mathrm{C}_{\mathrm{p}}{ }^{\circ}=40.04 \mathrm{~J} /(\mathrm{mol} \cdot \mathrm{K})\right)$. From these values and $\log \mathrm{K}^{\circ}, \Delta_{\mathrm{f}} \mathrm{G}^{\circ}$ and $\Delta_{\mathrm{f}} \mathrm{H}^{\circ}$ were calculated using the Nagra/PSI thermodynamic data base [56]. The density was taken from Raade [64]. 


\subsubsection{Sample preparation for hydration experiments}

242 For isothermal calorimetry and for phase analyses at each hydration step $(6 \mathrm{~h}, 1,3,7,28 \mathrm{~d})$ an 243 appropriate amount of paste (10 g except for mixes with artinite, where $5 \mathrm{~g}$ were used) was 244 mixed by hand for 2 minutes using a spatula. The powders were premixed by hand, with the 245 exception of $\mathrm{NaHCO}_{3}$, which was dissolved in the mixing water prior to use.

246 The samples for phase analysis were stored in a sealed PE container at $20^{\circ} \mathrm{C}$ until testing. For 247 hydration stoppage, the samples were gently crushed and stored in isopropanol during 15 248 minutes. Subsequently, the material was filtered, washed with isopropanol and rinsed with 249 diethyl ether to remove the isopropanol. Then the samples were dried during 8-10 minutes at $25040^{\circ} \mathrm{C}$, and if necessary stored in a desiccator under nitrogen atmosphere to minimize 251 carbonation prior to analysis. This sample stoppage method is generally recommended for 252 hydrated cementitious systems [69-72] and is gentler than the one used in the previous study 253 [46], where the hydration was stopped using acetone followed by drying at $60^{\circ} \mathrm{C}$ until 254 constant weight.

255 Before further analysis, the samples were freshly ground by hand below a particle size of 63 $256 \mu \mathrm{m}$ using an agate mortar.

\subsubsection{Isothermal calorimetry}

259 Isothermal conduction calorimetry was performed using a Thermometric TAM Air instrument 260 at $20^{\circ} \mathrm{C}$. Approximately 5-6 g of freshly mixed paste were transferred into a glass vial, which was then capped and placed into the calorimeter. Due to the external mixing, the initial heat peak could not be captured. The heat flow was recorded for 72 hours. Cumulative heat was determined by integration of the heat flow data, omitting the first 30 min after mixing. 


\subsubsection{X-ray diffraction}

266 X-ray diffraction analyses (XRD) were performed with a Panalytical X'Pert Pro in a $\Theta-\Theta$

267 configuration using CoK $\alpha$-radiation and the $\mathrm{X}^{\prime}$ Celerator detector. The samples were scanned 268 between $5^{\circ}$ and $115^{\circ} 2 \theta$ for 45 minutes. The consumption of $\mathrm{MgO}$ in the hydrated samples 269 was assessed semi-quantitatively by fitting peak areas using $\mathrm{CaF}_{2}$ as an external standard for 270 the intensity correction. After quantification, the results were recalculated according to [70] to $271100 \mathrm{~g}$ unhydrated binder using the weight losses of the unhydrated binder and the hydrated 272 pastes as determined by thermogravimetry (Eq. 2):

273

$274 \quad M O_{B}=M g O_{H} \cdot \frac{W_{H}}{W_{B}}$

275 with $\mathrm{MgOB}_{\mathrm{B}}=\mathrm{MgO}$ content in $\mathrm{g}$ per $100 \mathrm{~g}$ of unhydrated binder, $\mathrm{MgOH}=\mathrm{MgO}$ content in $\mathrm{g}$ 276 per $100 \mathrm{~g}$ of the hydrated sample, $\mathrm{W}_{\mathrm{B}}=$ ignited weight $\left(980^{\circ} \mathrm{C}\right)$ of the unhydrated binder, $\mathrm{W}_{\mathrm{H}}$ $277=$ ignited weight $\left(980^{\circ} \mathrm{C}\right)$ of the hydrated paste.

\subsubsection{Thermogravimetry}

280 Thermogravimetric analyses (TGA) were performed using a Mettler Toledo TGA/SDTA 851e 281 instrument under nitrogen atmosphere. Weight changes were measured while heating about $28250 \mathrm{mg}$ samples from $30-980^{\circ} \mathrm{C}$ with a heating rate of $20^{\circ} \mathrm{C}$ per minute in $150 \mu \mathrm{L}$ alumina 283 crucibles. Chemically bound water referred to $100 \mathrm{~g}$ unhydrated binder can be calculated 284 according to [70] using Eq. (3), subtracting the bound water already present in the unhydrated 285 binder originating from the hydromagnesite. Furthermore, it was assumed that no further 286 carbonation occurred during hydration, sample preparation and TGA measurement. 
$b w=\frac{W L_{H}}{W_{H}} \cdot W_{B}-W L_{B}=\frac{100-W_{H}}{W_{H}} \cdot W_{B}-\left(100-W_{B}\right)$

289 with bw $=$ bound water weight in $\mathrm{g}$ per $100 \mathrm{~g}$ unhydrated binder, $\mathrm{W}_{\mathrm{B}}=$ ignited weight $\left(980^{\circ} \mathrm{C}\right)$ 290 of the unhydrated binder, $\mathrm{WL}_{\mathrm{B}}=100-\mathrm{W}_{\mathrm{B}}=$ weight loss $\left(980^{\circ} \mathrm{C}\right)$ of the unhydrated binder, $\mathrm{W}_{\mathrm{H}}$

$291=$ ignited weight $\left(980^{\circ} \mathrm{C}\right)$ of the hydrated paste, $\mathrm{WLH}_{H}=100-\mathrm{W}_{\mathrm{H}}=$ weight loss $\left(980^{\circ} \mathrm{C}\right)$ of the 292 hydrated paste.

294 For selected samples, TGA measurements were carried out using a Netzsch STA 449 F3

295 Jupiter TGA apparatus coupled with a Bruker Fourier-transform infrared (FT-IR)

296 spectrometer for the analysis of the exhaust gases. The same temperature range and heating 297 rate were chosen as for the other TGA instrument. The infrared absorbances of $\mathrm{H}_{2} \mathrm{O}$ and $\mathrm{CO}_{2}$ were integrated in the ranges of 3400-4000 $\mathrm{cm}^{-1}$ (O-H stretching vibration) and 2200-2450 $\mathrm{cm}^{-1}\left(\mathrm{C}=\mathrm{O}\right.$ stretching vibration), respectively, and used as relative measures of $\mathrm{H}_{2} \mathrm{O}$ and $\mathrm{CO}_{2}$ 300 contents in the exhaust gases.

\subsubsection{Raman spectroscopy}

303 The Raman spectra were measured with a Bruker Senterra instrument of $5 \mathrm{~cm}^{-1}$ spectral 304 resolution, using a $532 \mathrm{~nm}$ laser $(20 \mathrm{~mW})$ at room temperature and with a $\times 50$ objective lens. 305 The spectral acquisition time was $40 \mathrm{~s}$, and 5 spectra were accumulated for each sample.

\section{$307 \quad 3 \quad$ Results}

\section{$308 \quad 3.1 \quad$ Thermodynamic modelling}

309 Thermodynamic modelling reveals that artinite, $\mathrm{Mg}_{2}\left(\mathrm{CO}_{3}\right)(\mathrm{OH})_{2} \cdot 3 \mathrm{H}_{2} \mathrm{O}$, should be the 310 thermodynamic stable hydrate phase in MgO-hydromagnesite blends (Fig. 2) as suggested 311 previously [46], but it seems to form experimentally only below $15^{\circ} \mathrm{C}$ [63]. Based on artinite

312 formation, a ratio of $80 \%$ hydromagnesite and $20 \% \mathrm{MgO}$ would be the optimum to 313 incorporate as much $\mathrm{CO}_{2}$ in the mix as possible. However, other hydrates, whose 
314 compositions and thermodynamic properties are not known and thus cannot be predicted by

315 thermodynamic modelling, might be present as well. The $\mathrm{pH}$ of the paste containing only

316 brucite formed by the hydration of pure $\mathrm{MgO}$ is calculated to be 10.6 . When hydromagnesite

317 is added up to 80 mass- $\%$, and artinite is present in the calculated hydrate assemblage, $\mathrm{pH}$

318 drops to 10.4. Beyond 80 mass- $\%$ of hydromagnesite, no brucite, but excess hydromagnesite

319 is present, and $\mathrm{pH}$ drops to 9.5. Suspensions of technical $\mathrm{MgO}$ and hydromagnesite show

320 similar behaviour $[46,48,49]$, however their $\mathrm{pH}$ values are higher due to the presence of

321 minor elements.

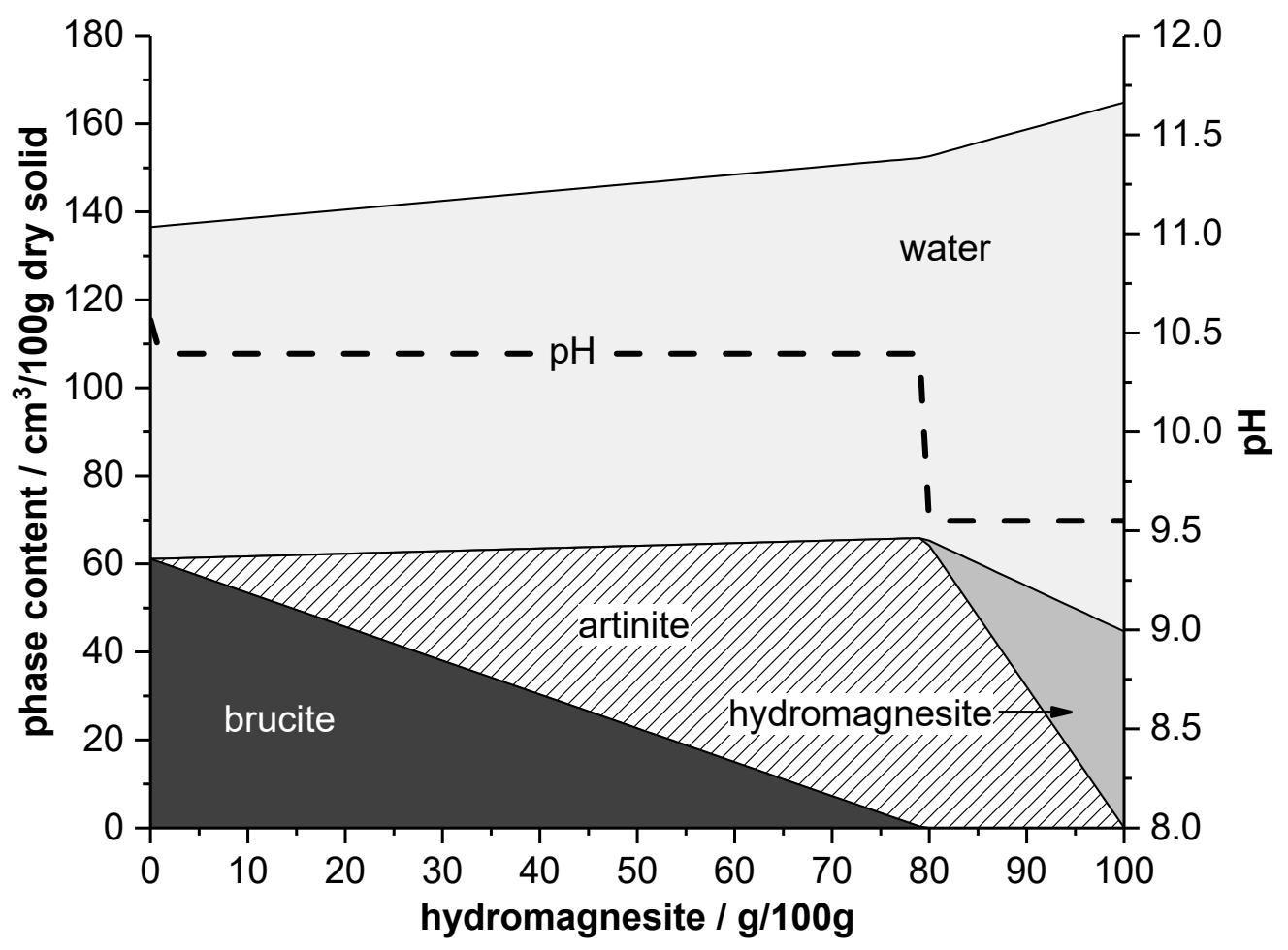

324 Fig. 2: Thermodynamic modelling of the stable hydrate assemblage in MgO-hydromagnesite 325 blends hydrated at $20^{\circ} \mathrm{C}$ using a water/solid ratio of 1.20 . 


\subsection{Isothermal calorimetry}

329 The replacement of 30 or $50 \%$ of the $\mathrm{MgO}$ with hydromagnesite accelerates the hydration of 330 the pure $\mathrm{MgO}$ at early ages (i.e. for about the first half day) as shown in Fig. 3a. The 331 replacement of $2 \%$ of hydromagnesite with artinite seeds does not show any significant

332 additional beneficial effect regarding acceleration of the hydration reactions. The replacement 333 of $2 \%$ of hydromagnesite by $\mathrm{NaHCO}_{3}$ leads to a slight retardation (Fig. 3b). This is in

334 agreement with the results for pure $\mathrm{MgO}$ and $\mathrm{MgO}$ blended with hydromagnesite seeds 335 published by other authors [48, 49]. With the addition of $\mathrm{NaHCO}_{3}$ the induction period ends 336 after approximately $2 \mathrm{~h}(\mathrm{MgO} / \mathrm{HY} 70 / 30: 40 \mathrm{~min})$, and the main hydration peak reaches its 337 maximum after approximately $5.5 \mathrm{~h}(\mathrm{MgO} / \mathrm{HY} 70 / 30: 40 \mathrm{~min})$.

338 The heat of hydration of $\mathrm{MgO}$ to brucite is estimated to be about $930 \mathrm{~J} / \mathrm{g} \mathrm{MgO}$ [73]. On this 339 basis, all samples were about $70-75 \%$ hydrated when the measurements stopped after three 340 days (Fig. 3c and 3d). Qualitatively, the early acceleration of $\mathrm{MgO}$ hydration shown here 341 seems to occur on a very similar time scale to that observed by [46] despite the fact that, in

342 their work, a much higher $\mathrm{MgO} / \mathrm{HY}$ ratio was used (90/10, as opposed to 70/30 and 50/50

343 here). It thus seems that the acceleratory effect may not be very strongly dependent on the

$344 \mathrm{HY} / \mathrm{MgO}$ ratio. Furthermore it seems that the $\mathrm{MgO}$ used in this study is of higher reactivity 345 compared to the one used in the previous study [46], where the authors found a degree of 346 hydration of approximately $50 \%$ after 7 days. 

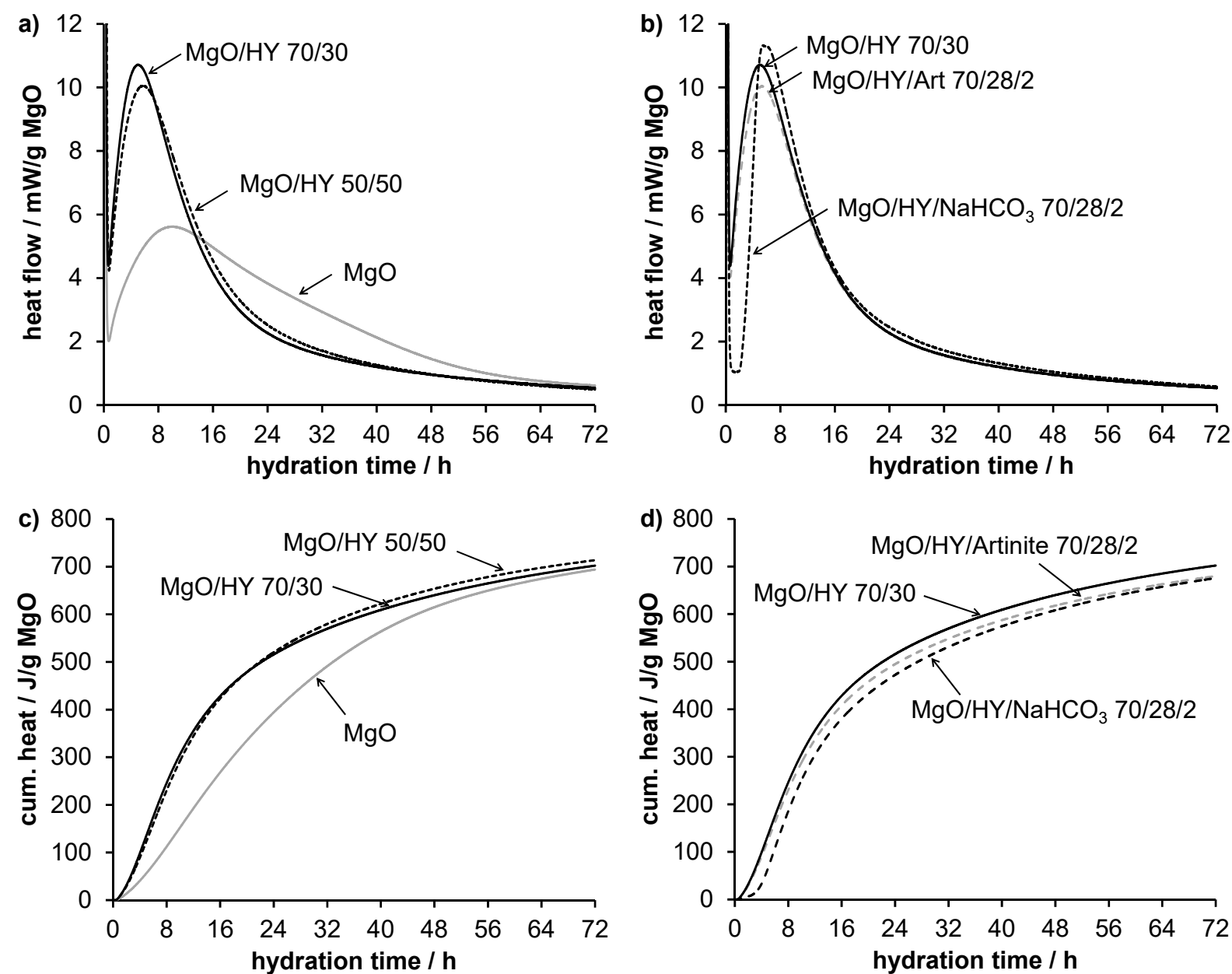

348 Fig. 3: Isothermal heat flow calorimetry of $\mathrm{MgO}$ hydrated in the presence of different

349 additions using a water/binder ratio of 1.20 ; a), b) heat flow, and c), d) cumulative heat.

\subsection{X-ray diffraction analyses}

$353 \mathrm{XRD}$ data allowed the degree of $\mathrm{MgO}$ consumption to be followed over much longer periods

354 of time than could be followed by calorimetry. The results shown in Fig. 4 are reasonably

355 consistent with the calorimetry data in the sense that most of the acceleratory effect of HY

356 addition occurs in the first day. The most important additional conclusion is that, by one

357 week, the $\mathrm{MgO}$ in all samples is over $90 \%$ consumed. The XRD data appear to show a

358 positive effect of artinite seeding at one day of hydration, but given that this XRD method is

359 far less quantitative than calorimetry at least during the first day of hydration, these data

360 cannot be considered to be proof of such a beneficial effect, which is not seen in the 
361 calorimetry data. In agreement to calorimetry, the addition of $\mathrm{NaHCO}_{3}$ seems to retard the 362 reaction of $\mathrm{MgO}$.

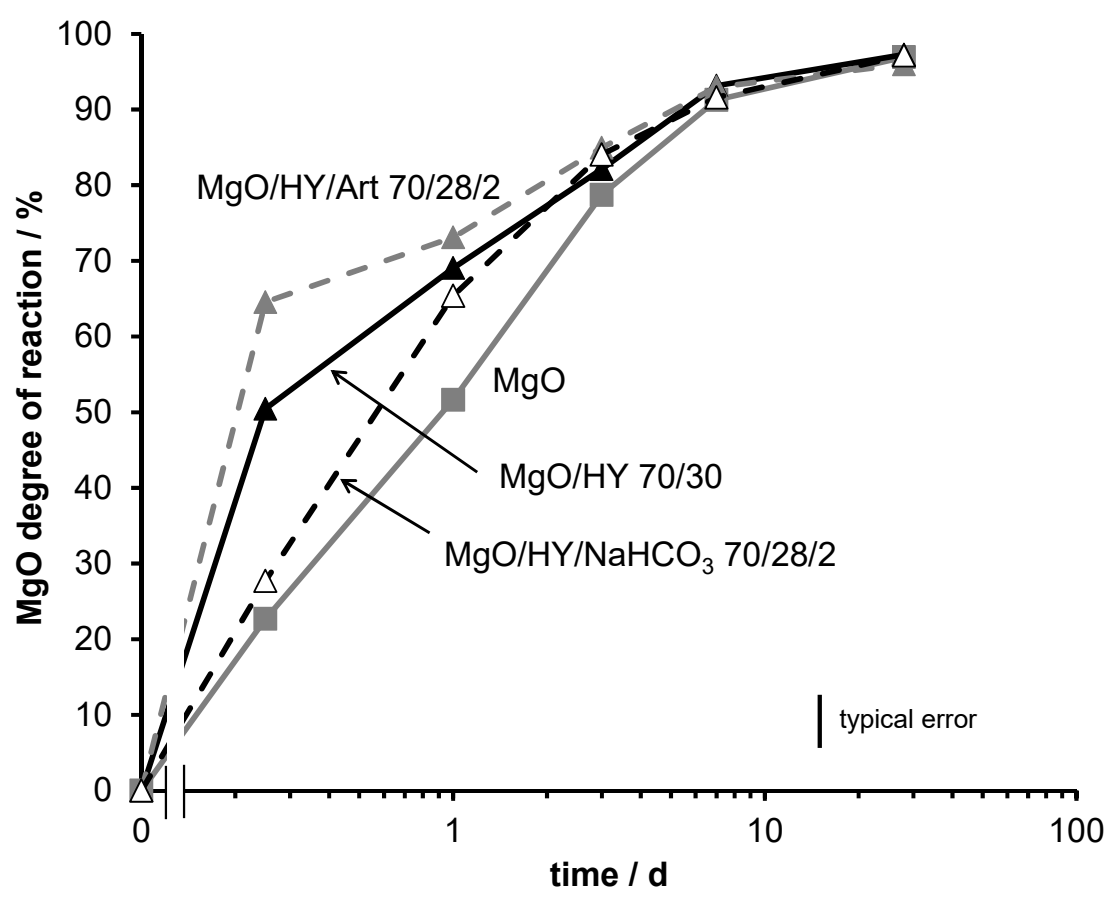

Fig. 4: Reaction degree of $\mathrm{MgO}$ as determined by XRD. The sample $\mathrm{MgO} / \mathrm{HY}$ 50/50 was omitted in the graph as its reaction degrees of $\mathrm{MgO}$ were very similar (slightly higher) than for $\mathrm{MgO} / \mathrm{HY} 70 / 30$.

X-ray diffraction patterns for the hydration of pure $\mathrm{MgO}$ pastes from 6 hours to 28 days are

371 shown in Fig. 5a. From 1 day to 28 days the disappearance of periclase and the appearance of a crystalline brucite with sharp diffraction peaks are observed.

373 The XRD patterns of the sample $\mathrm{MgO} / \mathrm{HY} 70 / 30$ are displayed in Fig. 5b. In this case the

374 scans are far more complex due to the presence of hydromagnesite reflections, but those peaks

375 do not appear to change significantly during the hydration. As expected, periclase disappears

376 and brucite appears in its place, but the brucite reflections are extremely broad, as has been observed before whenever a reactive magnesium carbonate is present [46]. Furthermore, the 
maxima of the brucite reflections are also shifted compared to the ones in the sample with $\mathrm{MgO}$ only, i.e. from $21.6^{\circ} 2 \Theta \mathrm{CoK} \alpha(\mathrm{d}=4.77 \AA)$ to $22.6^{\circ} 2 \Theta \mathrm{CoK} \alpha(\mathrm{d}=4.57 \AA)$, and from $44.4^{\circ} 2 \Theta \mathrm{CoK} \alpha(\mathrm{d}=2.37 \AA)$ to $44.2^{\circ} 2 \Theta \mathrm{CoK} \alpha(\mathrm{d}=2.38 \AA)$.

But also two additional broad reflections that were not reported before by [46] can be recognized. One occurs at a very low angle (about 5.5 $2 \Theta \mathrm{CoK} \alpha, \mathrm{d}=18.6 \AA$ ) which we tentatively refer to as "dypingite-like" since it is not far away from the low angle peak reported for dypingite $\left(6.7^{\circ} 2 \Theta \mathrm{CoK} \alpha, \mathrm{d}=15.2 \AA\right)$ [64]. Another broad peak occurs at approximately $16.5-19.5^{\circ} 2 \Theta \operatorname{CoK} \alpha(\mathrm{d}=6.2-5.3 \AA)$, which develops with time and well separated from expected brucite peaks. The assignment of this reflection remains unclear, but it might be due to the presence of an unknown amorphous magnesium carbonate. De Vito et al. synthesized amorphous magnesium carbonate by precipitation from magnesium chloride solutions using gaseous $\mathrm{CO}_{2}$ [74]. Their product was mainly X-ray amorphous, but showed a tiny reflection centred at a d-value of approximately $6.1 \AA$, which is similar to the d-value of the broad reflection at approximately $16.5-19.5^{\circ} 2 \Theta \mathrm{CoK} \alpha$ shown in Fig. 5b. The same research group investigated the $\mathrm{CO}_{2}$ sequestration by magnesium containing wastewater [75] When using high $\mathrm{Mg}$ concentrations and high $\mathrm{CO}_{2}$ fluxes amorphous magnesium carbonates were formed, and the authors could identify dypingite in samples stored for five months. Also in those samples an unidentified reflection with a d-value centred at approximately $6.1 \AA$ can be recognized.

When 2 mass- $\%$ artinite seed crystals are added, giving the $\mathrm{MgO} / \mathrm{HY} /$ artinite 70/28/2 blend, the artinite reflections are very sharp and clearly visible both in the unhydrated and hydrated pastes (Fig. 5c). They do not disappear with time, but neither can it be said unequivocally that they increase with hydration time. There seem to be random variations in their intensities, but they clearly do not lead to a significant diminution of the HY peaks, so there is no qualitative evidence for formation of artinite at the expense of hydromagnesite. Meanwhile, the two previously discussed reflections observed in the artinite-free $\mathrm{MgO} / \mathrm{HY} 70 / 30$ blend are formed 
404 in essentially the same way as in the absence of artinite seed crystals. Similar results as for the

$405 \mathrm{MgO} / \mathrm{HY} 70 / 30$ blend are obtained with the addition of $\mathrm{NaHCO}_{3}$, and with the $\mathrm{MgO} / \mathrm{HY}$

$40650 / 50$ blend (not shown). Thus, from semi-quantitative XRD scans, there is no evidence that

407 the addition of either artinite seed crystals or $\mathrm{NaHCO}_{3}$ significantly changes the nature of the 408 hydration products.

409

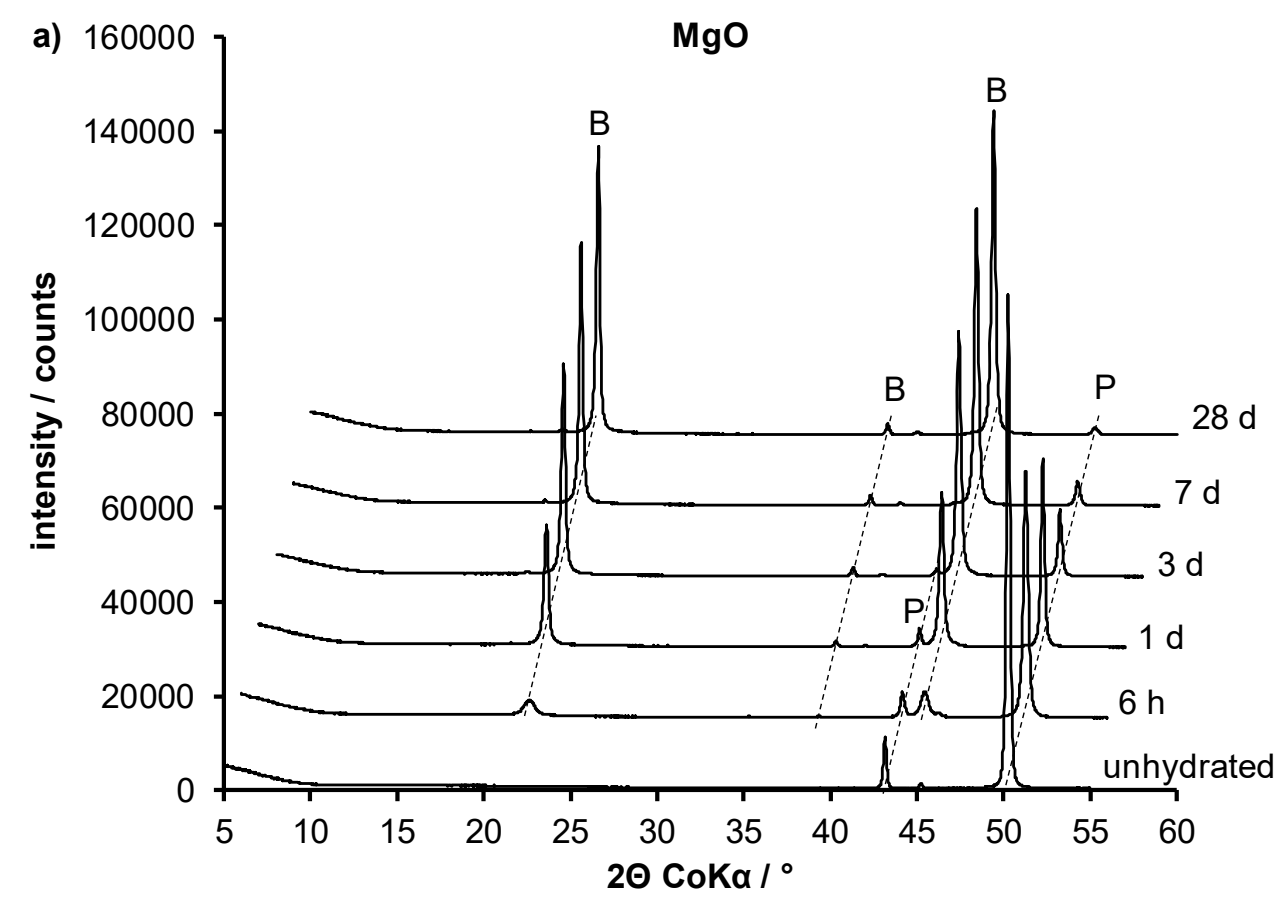

410

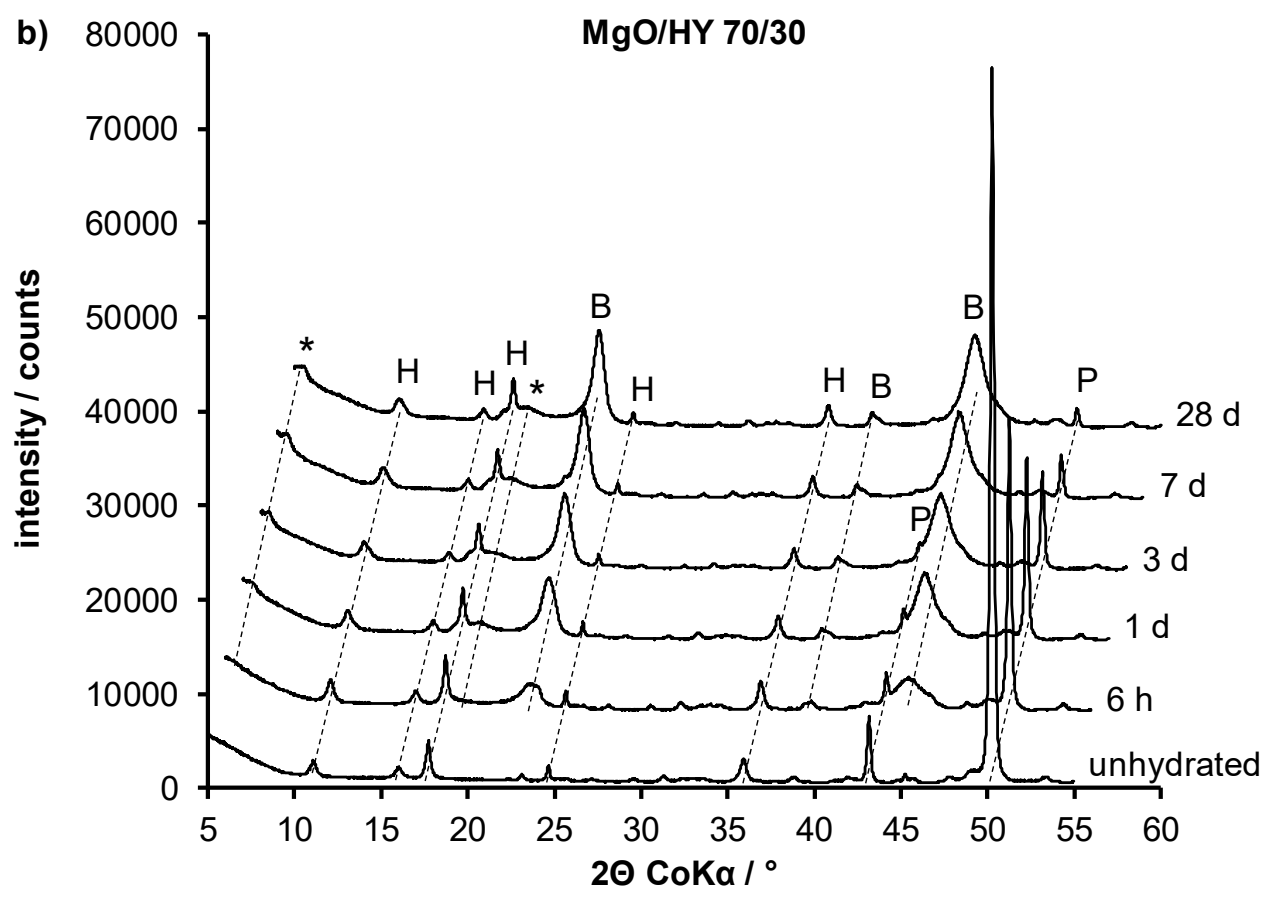




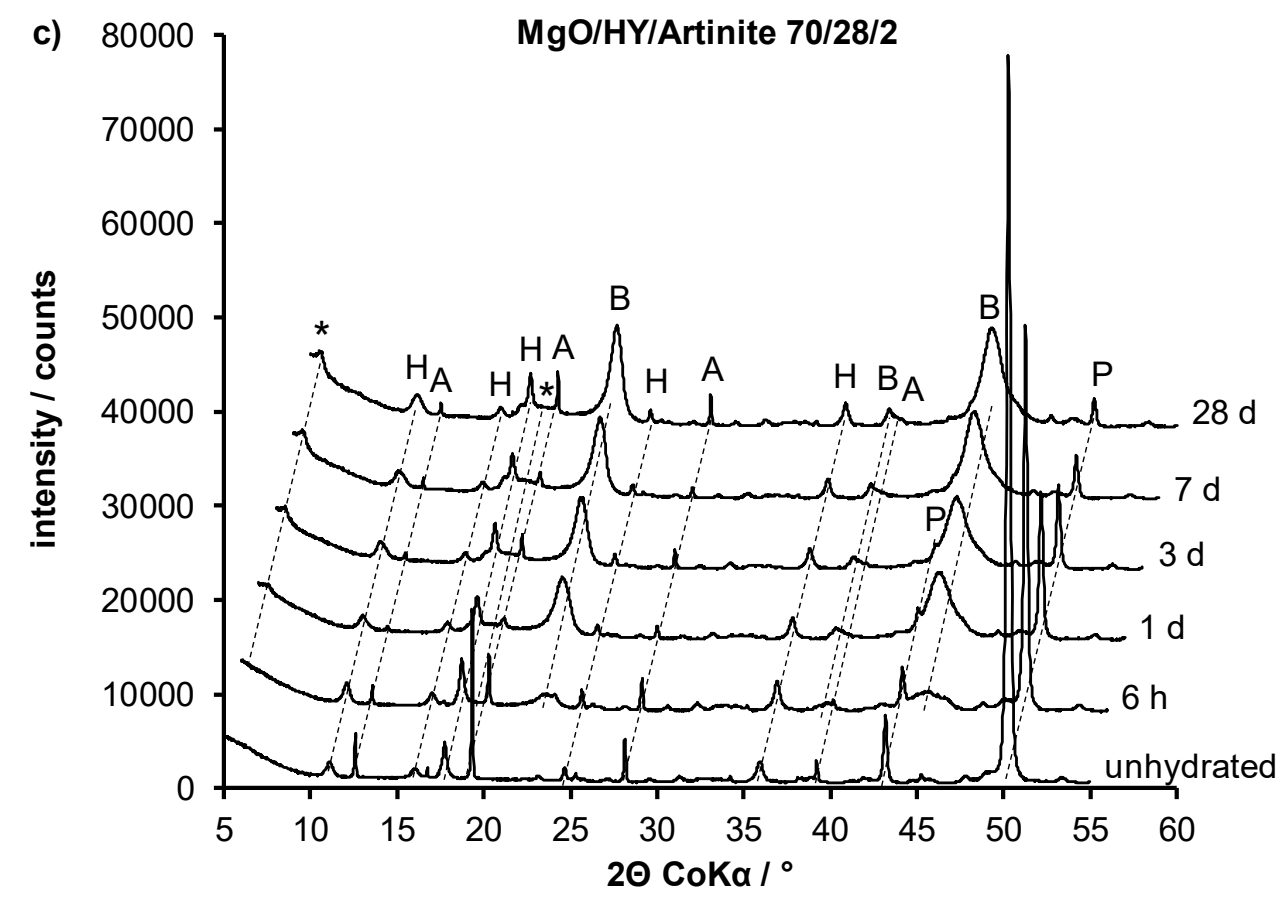

Fig. 5: XRD patterns after different hydration times of a) $\mathrm{MgO}$, b) $\mathrm{MgO} / \mathrm{HY} 70 / 30$, c)

$414 \mathrm{MgO} / \mathrm{HY} /$ Artinite $70 / 28 / 2 . \mathrm{A}=$ artinite, $\mathrm{B}=$ brucite, $\mathrm{H}=$ hydromagnesite, $\mathrm{P}=$ periclase, * $=$

415 reflections which cannot be assigned unambiguously. Note that the scale of the y-axis differs 416 between a) and b), c), respectively.

\subsection{Thermogravimetric analyses}

420 Fig. 6a shows the TGA analyses of hydrated $\mathrm{MgO}$ pastes. As expected, increasing amounts of

421 brucite are formed with increasing hydration times.

422 TGA analyses of hydrated pastes of $\mathrm{MgO} / \mathrm{HY} 70 / 30$ shows one particularly interesting and 423 apparently novel feature: the appearance of a dehydration peak centred at about $100^{\circ} \mathrm{C}$, as 424 seen in Fig. 6b. This peak is not present in pure hydromagnesite, nor in the initial blend of $425 \mathrm{MgO}$ and hydromagnesite that was hydrated in this experiment, and nor does it appear when 426 pure periclase is hydrated on its own. It has formed already by the first stopped hydration 427 measurement at 6 hours, and does not change significantly after that. In total amplitude it 428 represents about a 5\% mass loss by mass of the hydrated paste. Dypingite loses one mole of 
$429 \mathrm{H}_{2} \mathrm{O}$ at around $100^{\circ} \mathrm{C}[64,65,76]$, and it could be speculated that the TGA water loss at 430 around $100^{\circ} \mathrm{C}$ attributes to the "dypingite-like" phase identified by XRD and/or to the poorly 431 crystalline brucite, which might be able to bind additional water.

432 With the help of TGA measurements of pure hydromagnesite, see also [67, 77], and the $433 \mathrm{MgO} / \mathrm{HY} 70 / 30$ sample hydrated for 28 days, subsequent TGA mass loss peaks can be 434 simplistically attributed to:

435 (a) loss of the hydrate water from hydromagnesite at about $270^{\circ} \mathrm{C}$;

436 (b) dehydration of $\mathrm{OH}$ groups in both hydromagnesite and brucite at about $400^{\circ} \mathrm{C}$;

437 (c) decarbonation of the carbonate groups remaining from hydromagnesite at about $520^{\circ} \mathrm{C}$.

438 However, TGA-FTIR analysis of pure hydromagnesite (Fig. 7a) and of the MgO/HY 70/30

439 sample hydrated for 28 days (Fig. 7b) shows that there is actually a considerable amount of 440 carbonate lost also under the peak at $400^{\circ} \mathrm{C}$, and some water lost under the $520^{\circ} \mathrm{C}$ peak. 


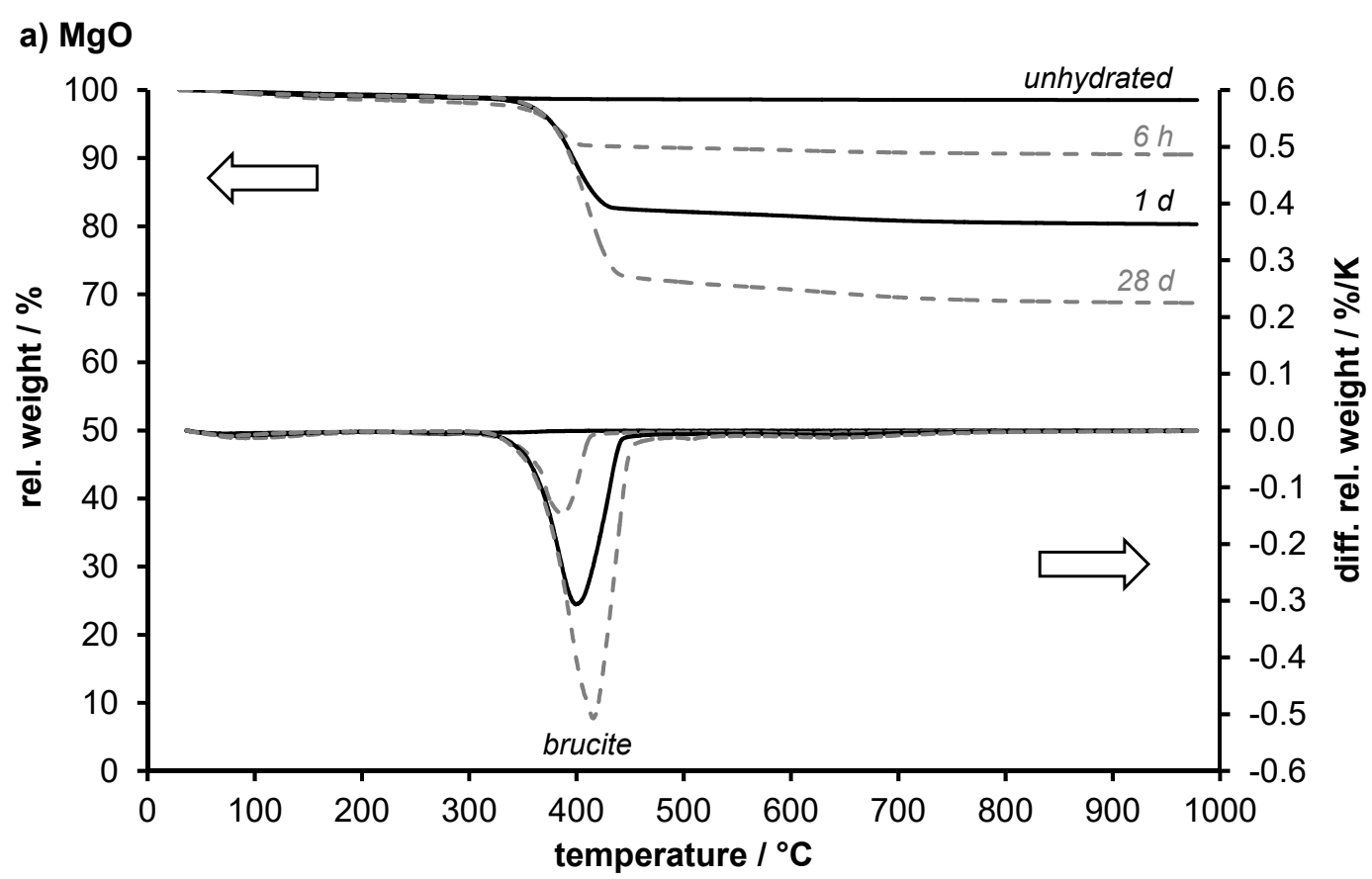

443

b) $\mathrm{MgO} / \mathrm{HY} 70 / 30$

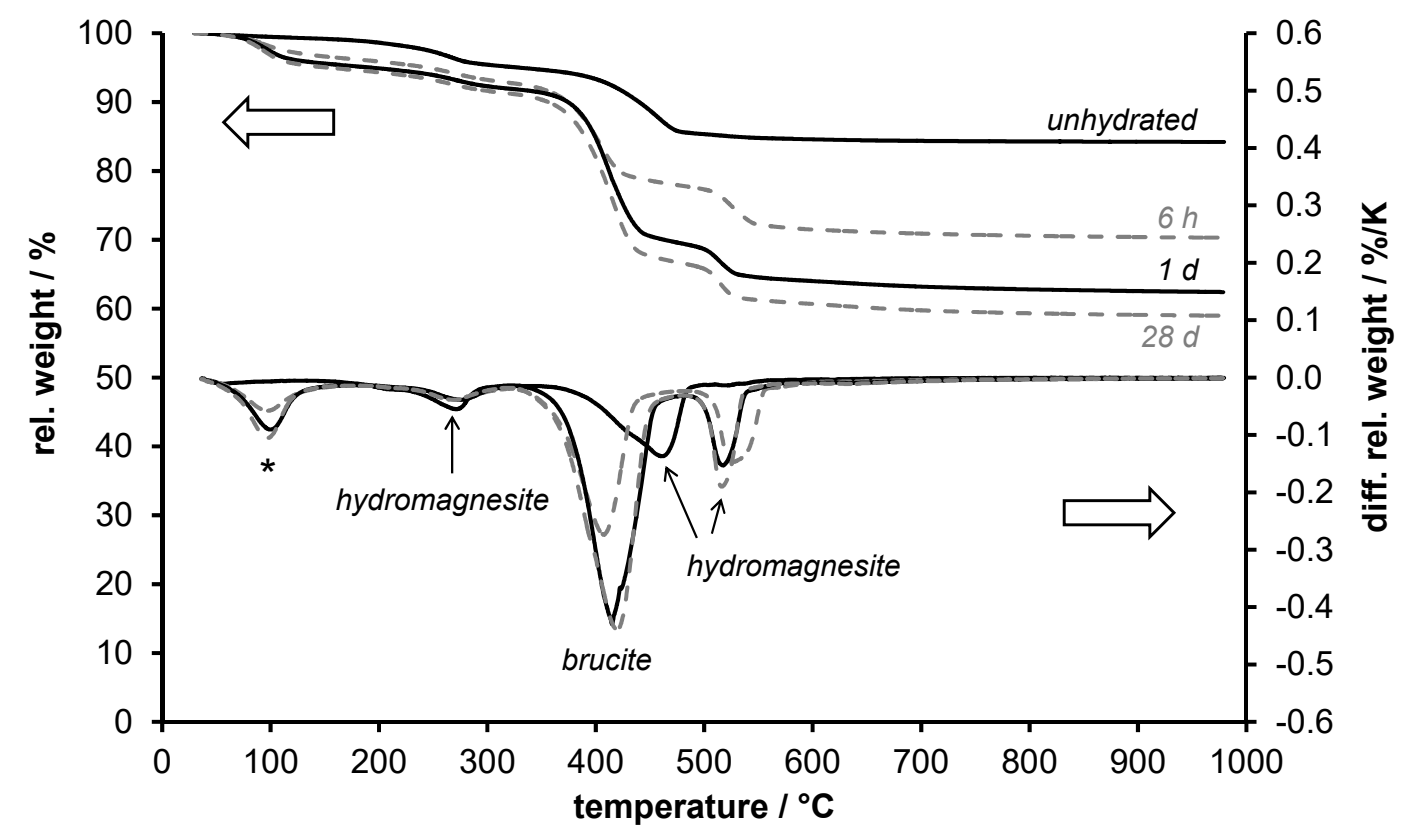

445 Fig. 6: Thermogravimetric analyses after different hydration times of a) $\mathrm{MgO}$, b) $\mathrm{MgO} / \mathrm{HY}$

$44670 / 30$. The samples after 3 and 7 days of hydration are omitted. “*” marks the dehydration

447 peak centred at about $100^{\circ} \mathrm{C}$. 

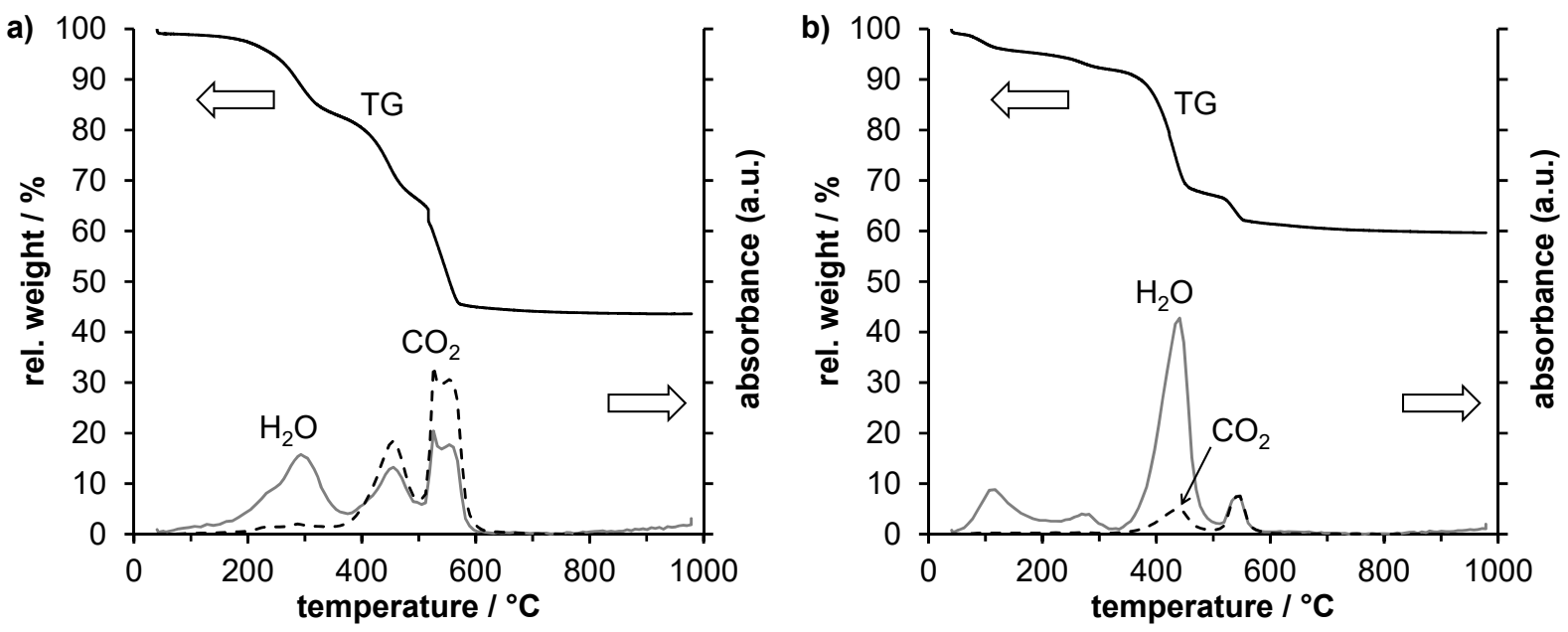

450 Fig. 7: Thermogravimetric analysis coupled with FT-IR of a) pure hydromagnesite and b)

$451 \mathrm{MgO} / \mathrm{HY} 70 / 30$ hydrated for 28 days.

454 Fig. 8a shows the amount of bound water referred to $100 \mathrm{~g}$ unhydrated binder for $\mathrm{MgO}$ and 455 the two $\mathrm{MgO} / \mathrm{HY}$ blends (70/30 and 50/50). In agreement with calorimetry and XRD results, 456 an acceleration of the hydration reactions can be observed when hydromagnesite is added to $457 \mathrm{MgO}$, while the amount of bound water after 28 days is in the same order for all three 458 mixtures. However, when normalizing the amount of bound water to the amount of $\mathrm{MgO}$ in 459 the binder (Fig. 8b), a significant increase of the bound water content with increasing amount 460 of hydromagnesite in the blend can be observed. When the amount of bound water is 461 recalculated as $\mathrm{mol} \mathrm{H}_{2} \mathrm{O}$ per mol $\mathrm{MgO}$ reacted, values of $1.0(\mathrm{MgO}$, referring to the formation 462 of brucite), $2.0(\mathrm{MgO} / \mathrm{HY} 70 / 30)$ and $3.3(\mathrm{MgO} / \mathrm{HY} 50 / 50) \mathrm{mol}_{2} \mathrm{O}$ per mol $\mathrm{MgO}$ are

463 derived. Thus it can be concluded that in the presence of hydromagnesite more water is bound 464 in hydrate phases than can be explained by the hydration of $\mathrm{MgO}$ to brucite, as also suggested 465 by the presence of the TGA water loss peak centred at around $100^{\circ} \mathrm{C}$. 

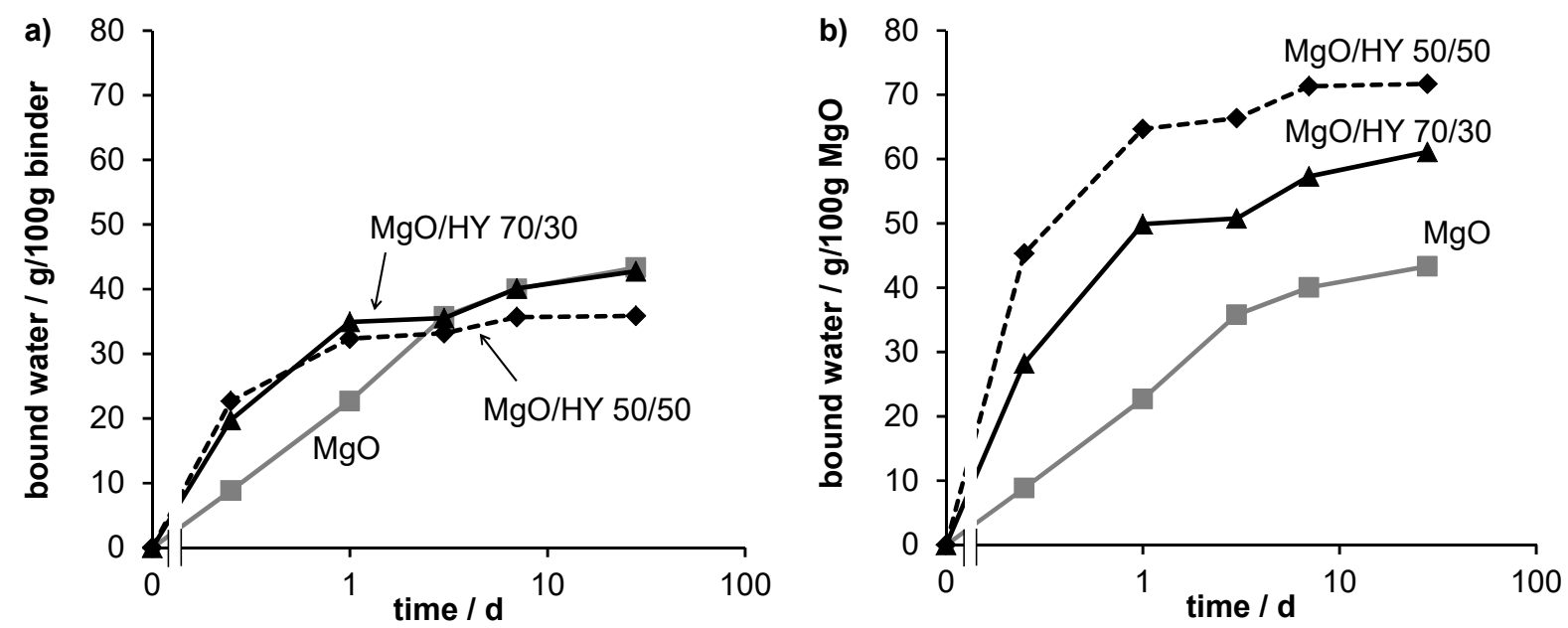

467 Fig. 8: Influence of the $\mathrm{MgO} /$ hydromagnesite ratio on the amount of water bound in the hydration reactions, normalized to (a) unhydrated binder and (b) unhydrated $\mathrm{MgO}$.

\subsection{Raman spectroscopy}

472 Raman spectroscopy of the $\mathrm{MgO} / \mathrm{HY} 70 / 30$ blend hydrated for $28 \mathrm{~d}$ shows in the region

473 below $1200 \mathrm{~cm}^{-1}$ the presence of brucite as identified by two main peaks at $445 \mathrm{~cm}^{-1}$ and 280

$474 \mathrm{~cm}^{-1}$, and a broad peak centred at around $730 \mathrm{~cm}^{-1}$ (Fig. 9a) in agreement to [78]. The peak at

$4751120 \mathrm{~cm}^{-1}$ in the hydrated $\mathrm{MgO} / \mathrm{HY} 70 / 30$ blend refers to the symmetrical stretching vibration

476 of the $\mathrm{CO}_{3}{ }^{2-}$ ion in hydromagnesite [46]. An additional weak peak at $1050 \mathrm{~cm}^{-1}$ (Fig. 9b)

477 formed in the $\mathrm{MgO} / \mathrm{HY} 70 / 30$ blend (and in all other hydrated blends of pure $\mathrm{MgO}$ with

478 hydromagnesite), but this peak does not correspond to a major peak of artinite, dypingite [79]

479 or any other known magnesium carbonate and so remains unassigned. The main Raman peak

480 of artinite, at about $1095 \mathrm{~cm}^{-1}$ (symmetrical stretching vibration of the $\mathrm{CO}_{3}{ }^{2-}$ ion [79]), was

481 not observed when no artinite seed crystals were added, although a weak broad peak close to

482 it is present and could indicate another amorphous phase related to artinite. But overall the

483 Raman evidence supports the conclusion that no significant amounts of an artinite-like phase

484 form in this system. 

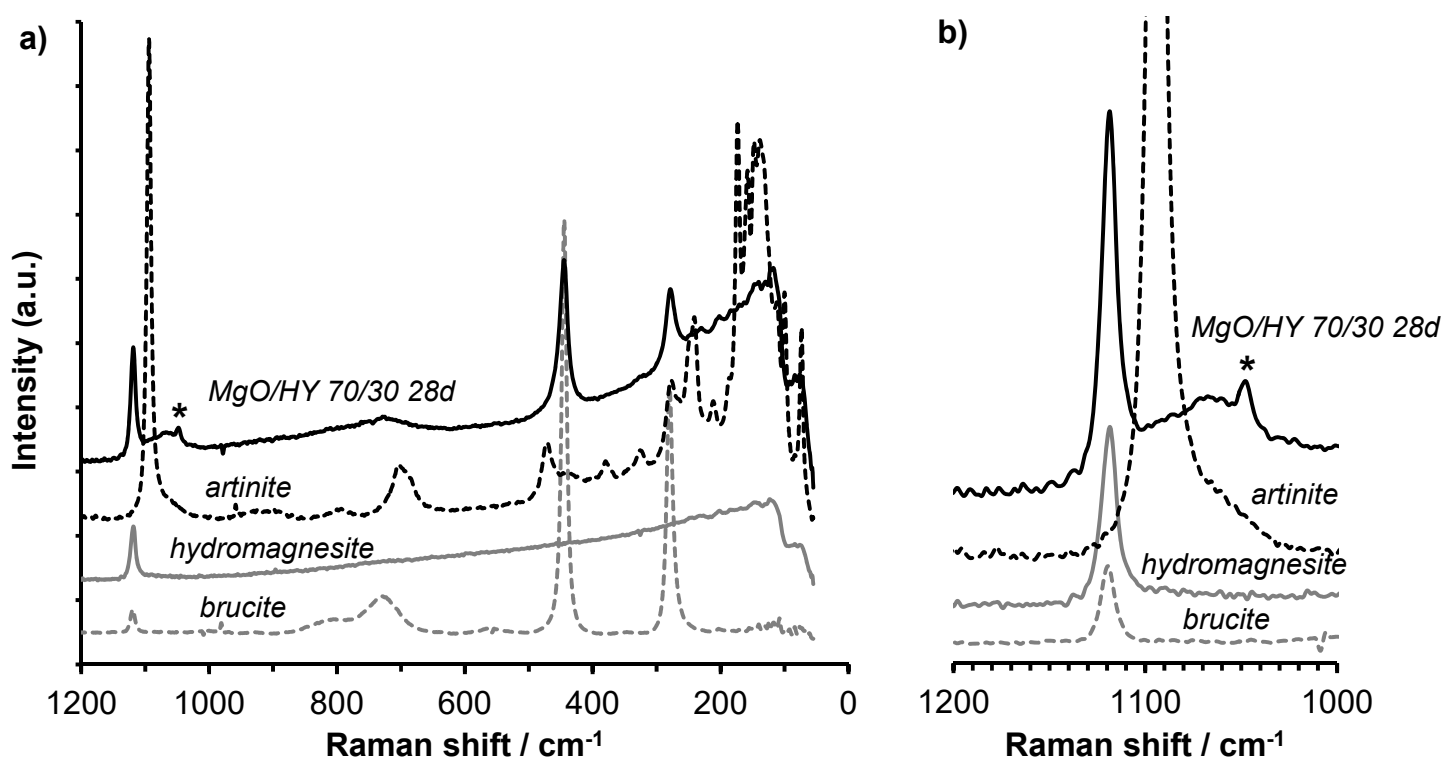

486

487 Fig. 9: Raman spectrum of $\mathrm{MgO} / \mathrm{HY} 70 / 30$ after $28 \mathrm{~d}$ of hydration in the range of a) 1200-55 $488 \mathrm{~cm}^{-1}$ and b) $1200-1000 \mathrm{~cm}^{-1}$. Raman spectra of brucite, hydromagnesite and artinite are shown 489 for comparison. $*=$ unassigned.

\section{Discussion and conclusions}

493 In agreement with a previous study [46] it was found that hydromagnesite accelerates the

494 reaction of $\mathrm{MgO}$. Blends of $\mathrm{MgO}$ with hydromagnesite were shown to provide strength

495 properties, which would be suitable to manufacture construction materials, but still significantly below the performance of Portland cement, while $\mathrm{MgO}$ alone does not provide

497 any strength $[43,44,46]$. This was confirmed within this study using mortars based on a 498 technical $\mathrm{MgO}$ blended with hydromagnesite, see Appendix.

499 However, the results obtained in this work point towards negative conclusions on both of our 500 initial hypotheses.

501 The hypothesis that artinite is the stable hydrate in a mixture of brucite and hydromagnesite 502 (HY), based on a thermodynamic calculation, is not supported by our observation as the 
seeding of the hydrating $\mathrm{MgO}-\mathrm{HY}$ blends with finely ground natural artinite had no significant effect on the rate of hydration or on the final product assemblage. However, the hydration was followed up to 28 days only, and the samples might not have reached equilibrium.

The hypothesis that addition of a soluble salt with a common ion, sodium bicarbonate, could accelerate the hydration of $\mathrm{MgO}$ blends is also not supported by our data. It appears to have no significant effect on the rate of hydration (a slight retardation of $\mathrm{MgO}$ dissolution is observed) or on the products of the hydration reactions.

However, there were important new observations in the TGA and XRD analyses. Because of the careful preparation procedure used to stop the hydration of the pastes prior to analyses, we were able to show that in the presence of hydromagnesite more water is bound in hydrate phases than can be explained by the formation of brucite only. The MgO-HY blends always produced a significant amount of an unknown hydrate with a thermal decomposition peak centred on about $100^{\circ} \mathrm{C}$. This hydrate formed quickly - it was already present after 6 hours of hydration and did not increase significantly after that. We hypothesise that this peak represents an amorphous or very poorly-crystalline phase that leads to cohesive binding in these blends.

XRD analyses revealed that in MgO-HY blends two reflections are present, one at $5.5^{\circ} 2 \Theta$ $\operatorname{CoK} \alpha(d=18.6 \AA)$, and a second broad reflection at about $16.5-19.5^{\circ} 2 \Theta \operatorname{CoK} \alpha(d=6.2-5.3$ $\AA$ ), which belong neither to hydromagnesite nor to brucite. It can be speculated that those reflections belong to an amorphous or very poorly crystalline phase containing the additional water observed by TGA.

Another difference between the hydrated $\mathrm{MgO}-\mathrm{HY}$ pastes and the pure $\mathrm{MgO}$ paste is the observation of very broad diffraction peaks for brucite whenever hydromagnesite is present. It is tempting to speculate that the low-temperature TGA peak might be associated with water 
528 weakly bound to this very poorly crystalline form of brucite and/or to the amorphous or

529 poorly crystalline phase identified by XRD.

530 Further investigations to unravel the nature of hydrate phases in the MgO-hydromagnesite

531 system and their role regarding strength formation will be necessary.

532

533 5. Acknowledgements

534 Boris Ingold, Luigi Brunetti and Daniel Käppeli are acknowledged for their assistance in the

535 lab, Andreas Leemann for taking the photograph of the artinite mineral, and Ellina Bernard, 536 Andrea Mancini and Alessio di Giacomo for assistance with Raman and TG-FT-IR. Barbara

537 Lothenbach is acknowledged for fruitful discussions and critical review of the manuscript. 538

539 


\section{References}

541 [1] World Business Council for Sustainable Development (WBCSD) Cement Sustainability

542 Initiative (CSI), Cement Industry Energy and $\mathrm{CO}_{2}$ Performance - Getting the Numbers Right

543 (GNR), available at http://wbcsdservers.org/wbcsdpublications/cd_files/datas/business-

544 solutions/cement/pdf/CementIndustryEnergyAnd\%20CO2Performance.pdf, 2009.

545 [2] Cembureau, Activity Report 2016, available at https://cembureau.eu/media/1635/activity546 report-2016.pdf, (2017).

547 [3] J.G.J. Olivier, G. Janssens-Maenhout, J.A.H.W. Peters, J. Wilson, Long-term trend in 548 global $\mathrm{CO}_{2}$ emissions: 2011 Report, PBL Netherlands Environmental Assessment Agency, 549 The Hague, The Netherlands, available at http://www.pbl.nl/sites/default/files/cms/ 550 publicaties/C02\%20Mondiaal_\%20webdef_19sept.pdf, 2011.

551 [4] J.L. Provis, Green concrete or red herring? - future of alkali-activated materials, Adv. 552 Appl. Ceram., 113 (2014) 472-477.

553 [5] K.L. Scrivener, V.M. John, E.M. Gartner, Eco-efficient cements: Potential, economically 554 viable solutions for a low- $\mathrm{CO}_{2}$, cement-based materials industry, Report of the United Nations 555 Environment Programme, available at https://lmc.epfl.ch/files/content/users/184559/files/ 556 2016-UNEP\%20Report-Complete6.pdf, 2016.

557 [6] E. Gartner, Industrially interesting approaches to "low- $\mathrm{CO}_{2}$ " cements, Cem. Concr. Res., 55834 (2004) 1489-1498.

559 [7] M.C.G. Juenger, F. Winnefeld, J.L. Provis, J.H. Ideker, Advances in alternative 560 cementitious binders, Cem. Concr. Res., 41 (2011) 1232-1243.

561 [8] E. Gartner, H. Hirao, A review of alternative approaches to the reduction of $\mathrm{CO}_{2}$

562 emissions associated with the manufacture of the binder phase in concrete, Cem. Concr. Res., $56378(2015) 126-142$.

564 [9] H.-M. Ludwig, W. Zhang, Research review of cement clinker chemistry, Cem. Concr. 565 Res., 78 (2015) 24-37. 
[10] E. Gartner, T. Sui, Alternative cement clinkers, Cem. Concr. Res., 114 (2018) 27-39.

[11] S.A. Walling, J.L. Provis, Magnesia-based cements: A journey of 150 years, and cements 568 for the future?, Chem. Rev., 116 (2016) 4170-4204.

569 [12] S. Ruan, C. Unluer, Comparative life cycle assessment of reactive $\mathrm{MgO}$ and Portland 570 cement production, J. Clean Prod., 137 (2016) 258-273.

571 [13] M. Achternbosch, C. Kupsch, E. Nieke, G. Sardemann, Are new magnesia-based 572 cements the future? Part 1: Analysis of former developments, ZKG Int., 65 (2012) 64-72.

573 [14] R.M. Dheilly, A. Bouguerra, B. Beaudoin, J. Tudo, M. Queneudec, Hydromagnesite 574 development in magnesian lime mortars, Mater. Sci. Eng. A-Struct. Mater. Prop. Microstruct. 575 Process., 268 (1999) 127-131.

576 [15] M. Hänchen, V. Prigiobbe, R. Baciocchi, M. Mazzotti, Precipitation in the Mg-carbonate 577 system - effects of temperature and $\mathrm{CO}_{2}$ pressure, Chem. Eng. Sci., 63 (2008) 1012-1028. [16] M. Liska, L.J. Vandeperre, A. Al-Tabbaa, Influence of carbonation on the properties of reactive magnesia cement-based pressed masonry units, Adv. Cem. Res., 20 (2008) 53-64.

580 [17] L.J. Vandeperre, M. Liska, A. Al-Tabbaa, Microstructures of reactive magnesia cement 581 blends, Cem. Concr. Compos., 30 (2008) 706-714.

582 [18] P. De Silva, L. Bucea, V. Sirivivatnanon, Chemical, microstructural and strength 583 development of calcium and magnesium carbonate binders, Cem. Concr. Res., 39 (2009) 460465.

585 [19] C. Unluer, A. Al-Tabbaa, Impact of hydrated magnesium carbonate additives on the 586 carbonation of reactive $\mathrm{MgO}$ cements, Cem. Concr. Res., 54 (2013) 87-97.

587 [20] J. Morrison, G. Jauffret, J.L. Galvez-Martos, F.P. Glasser, Magnesium-based cements for $588 \quad \mathrm{CO}_{2}$ capture and utilisation, Cem. Concr. Res., 85 (2016) 183-191.

589 [21] G. Davila, J. Cama, S. Gali, L. Luquot, J.M. Soler, Efficiency of magnesium hydroxide 590 as engineering seal in the geological sequestration of $\mathrm{CO}_{2}$, Int. J. Greenh. Gas Control, 48 591 (2016) 171-185. 
[22] N.T. Dung, C. Unluer, Sequestration of $\mathrm{CO}_{2}$ in reactive $\mathrm{MgO}$ cement-based mixes with enhanced hydration mechanisms, Constr. Build. Mater., 143 (2017) 71-82.

[23] N.T. Dung, C. Unluer, Influence of nucleation seeding on the performance of carbonated

595

596

597

598

599

600

601

602

603

604

605

606

607

608

609

610

611

612

613

614

615

616

MgO formulations, Cem. Concr. Compos., 83 (2017) 1-9.

[24] L.W. Mo, F. Zhang, D.K. Panesar, M. Deng, Development of low-carbon cementitious materials via carbonating Portland cement-fly ash-magnesia blends under various curing scenarios: a comparative study, J. Clean Prod., 163 (2017) 252-261.

[25] S. Ruan, C. Unluer, Influence of mix design on the carbonation, mechanical properties and microstructure of reactive $\mathrm{MgO}$ cement-based concrete, Cem. Concr. Compos., 80 (2017) 104-114.

[26] W.J.J. Huijgen, R.N.J. Comans, Carbon dioxide sequestration by mineral carbonation, Literature Review Update 2003-2004, ECN-C-05-022, Energy Research Centre of The Netherlands, Petten, The Netherlands, available at https://www.ecn.nl/docs/library/report/2005/c05022.pdf, (2005).

[27] D.E. Giammar, R.G. Bruant, C.A. Peters, Forsterite dissolution and magnesite precipitation at conditions relevant for deep saline aquifer storage and sequestration of carbon dioxide, Chem. Geol., 217 (2005) 257-276.

[28] M.M. Maroto-Valer, D.J. Fauth, M.E. Kuchta, Y. Zhang, J.M. Andresen, Activation of magnesium rich minerals as carbonation feedstock materials for $\mathrm{CO}_{2}$ sequestration, Fuel Process. Technol., 86 (2005) 1627-1645.

[29] M. Hänchen, V. Prigiobbe, G. Storti, T.M. Seward, M. Mazzotti, Dissolution kinetics of fosteritic olivine at $90-150^{\circ} \mathrm{C}$ including effects of the presence of $\mathrm{CO}_{2}$, Geochim. Cosmochim. Acta, 70 (2006) 4403-4416.

[30] J.M. Matter, P.B. Kelemen, Permanent storage of carbon dioxide in geological reservoirs by mineral carbonation, Nat. Geosci., 2 (2009) 837-841. 
617 [31] V. Prigiobbe, G. Costa, R. Baciocchi, M. Hänchen, M. Mazzotti, The effect of $\mathrm{CO}_{2}$ and 618 salinity on olivine dissolution kinetics at $120^{\circ} \mathrm{C}$, Chem. Eng. Sci., 64 (2009) 3510-3515.

619 [32] A.A. Olajire, A review of mineral carbonation technology in sequestration of $\mathrm{CO}_{2}$, J. Pet. 620 Sci. Eng., 109 (2013) 364-392.

621 [33] E. Gartner, M. Gimenez, V. Meyer, A. Pisch, A novel atmospheric pressure approach to 622 the mineral capture of $\mathrm{CO}_{2}$ from industrial point sources, Thirteenth Annual Conference on 623 Carbon Capture, Utilization and Storage, April 28 - May 1, 2014, Pittsburgh, Pennsylvania, 624 USA.

625 [34] V.T. Luong, R. Amal, J.A. Scott, S. Ehrenberger, T. Tran, A comparison of carbon 626 footprints of magnesium oxide and magnesium hydroxide produced from conventional 627 processes, J. Clean Prod., 202 (2018) 1035-1044.

628 [35] L. Ogorodova, L. Melchakova, I. Kiseleva, E. Korytkova, Enthalpies of formation of 629 minerals of serpentine group, Vestnik Otdelenia Nauk O Zemle RAN, 27 (2009) 2-3.

630 [36] P.A. Davies, Solar thermal decomposition of desalination reject brine for carbon dioxide 631 removal and neutralisation of ocean acidity, Environ. Sci.-Wat. Res. Technol., 1 (2015) 131632137.

633 [37] H.L. Dong, E.H. Yang, C. Unluer, F. Jin, A. Al-Tabbaa, Investigation of the properties of $634 \mathrm{MgO}$ recovered from reject brine obtained from desalination plants, J. Clean Prod., 196 635 (2018) 100-108.

636 [38] C.Y. Wu, C. Chen, H.F. Zhang, Y.S. Tan, H.F. Yu, Preparation of magnesium oxysulfate 637 cement using magnesium-rich byproducts from the production of lithium carbonate from salt 638 lakes, Constr. Build. Mater., 172 (2018) 597-607.

639 [39] S. Yousefi, B. Ghasemi, M. Tajally, A. Asghari, Optical properties of MgO and $640 \mathrm{Mg}(\mathrm{OH})_{2}$ nanostructures synthesized by a chemical precipitation method using impure brine, 641 J. Alloy. Compd., 711 (2017) 521-529. 
642 [40] A. Jha, Revealed: The cement that eats carbon dioxide, The Guardian, available at 643 www.theguardian.com/environment/2008/dec/31/cement-carbon-emissions2008, 2008.

644 [41] N. Vlasopoulos, Waste minimisation through sustainable magnesium oxide cement 645 products, $\mathrm{PhD}$ Thesis, Imperial College, London, UK, (2007).

646 [42] N. Vlasopoulos, C.R. Cheeseman, Use of magnesium oxide-cement binders for the 647 production of blocks with lightweight aggregates, International Conference on Sustainable 648 Construction Materials and Technologies, Jun 11-13, 2007, Coventry, UK, (2007) 287-294. 649 [43] N. Vlasopoulos, C.R. Cheeseman, Binder composition, PCT Patent Application PCT/GB2009/001610, International Publication Number WO 2009/156740 A1 (12/30/2009).

651 [44] F. Zhang, Magnesium oxide based binders as low-carbon cements, PhD Thesis, Imperial 652 College, London, UK, (2012).

653 [45] M. Achternbosch, C. Kupsch, E. Nieke, G. Sardemann, Are new magnesia-based 654 cements the future? Part 2: Novacem - an assessment of new developments, ZKG Int., 65 $655 \quad$ (2012) 64-72.

656 [46] C. Kuenzel, F. Zhang, V. Ferrándiz-Mas, C.R. Cheeseman, E.M. Gartner, The 657 mechanism of hydration of MgO-hydromagnesite blends, Cem. Concr. Res., 103 (2018) 123658129.

659 [47] M. Collepardi, G. Rossi, M.C. Spiga, Hydration of tricalcium silicate in presence of 660 electrolytes, Ann. Chim., 61 (1971) 137-148.

661 [48] N.T. Dung, C. Unluer, Improving the carbonation of reactive MgO cement concrete via 662 the use of $\mathrm{NaHCO}_{3}$ and $\mathrm{NaCl}$, J. Mater. Civ. Eng., 30 (2018).

663 [49] N.T. Dung, C. Unluer, Performance of reactive $\mathrm{MgO}$ concrete under increased $\mathrm{CO}_{2}$ 664 dissolution, Cem. Concr. Res., 118 (2019) 92-101.

665 [50] E.M. van der Merwe, C. Strydom, A. Botha, Hydration of medium reactive industrial 666 magnesium oxide with magnesium acetate, J. Therm. Anal. Calorim., 77 (2004) 49-56.

667 [51] M. Akao, S. Iwai, Hydrogen-bonding of artinite, Acta Cryst. B, 33 (1977) 3951-3953. 
668 [52] H. Jagodzinski, Kristallstruktur und Fehlordnung des Artinits $\mathrm{Mg}_{2}\left[\mathrm{CO}_{3}(\mathrm{OH})_{2}\right] \cdot 3 \mathrm{H}_{2} \mathrm{O}$,

669 Tschermaks Mineral. Petrog. Mitt., 10 (1965) 297-330.

670 [53] P.M. de Wolff, The crystal structure of artinite, $\mathrm{Mg}_{2}(\mathrm{OH})_{2} \mathrm{CO}_{3} \cdot 3 \mathrm{H}_{2} \mathrm{O}$, Acta Cryst., 5

$671 \quad$ (1952) 286-287.

672 [54] T. Wagner, D.A. Kulik, F.F. Hingerl, S.V. Dmytrieva, GEM-Selektor geochemical

673 modelling package: TSolMod Library and data interface for multicomponent phase models,

674 Can. Mineral., 50 (2012) 1173-1195.

675 [55] D.A. Kulik, T. Wagner, S.V. Dmytrieva, G. Kosakowski, F.F. Hingerl, K.V. Chudnenko,

676 U.R. Berner, GEM-Selektor geochemical modeling package: revised algorithm and GEMS3K

677 numerical kernel for coupled simulation codes, Comput. Geosci., 17 (2013) 1-24.

678 [56] W. Hummel, U. Berner, E. Curti, F.J. Pearson, T. Thoenen, Nagra/PSI chemical

679 thermodynamic data base 01/01, Radiochim. Acta, 90 (2002) 805-813.

680 [57] H.C. Helgeson, J.M. Delany, H.W. Nesbitt, D.K. Bird, Summary and critique of the

681 thermodynamic properties of rock-forming minerals, Am. J. Sci., 278A (1978) 1-229.

682 [58] J.W. Johnson, E.H. Oelkers, H.C. Helgeson, SUPCRT92 - A software package for

683 calculating the standard molal thermodynamic properties of minerals, gases, aqueous species,

684 and reactions from 1 to 5000 bar and $01000^{\circ} \mathrm{C}$, Comp. Geosci., 18 (1992) 899-947.

685 [59] E. Königsberger, L.C. Königsberger, H. Gamsjäger, Low-temperature thermodynamic

686 model for the system $\mathrm{Na}_{2} \mathrm{CO}_{3}-\mathrm{MgCO}_{3}-\mathrm{CaCO}_{3}-\mathrm{H}_{2} \mathrm{O}$, Geochim. Cosmochim. Acta, 63 (1999)

$687 \quad 3105-3119$.

688 [60] R.J. Hill, J.H. Canterford, F.J. Moyle, New data for lansfordite, Mineral. Mag., 46 (1982)

$689 \quad 453-457$.

690 [61] R.A. Robie, B.S. Hemingway, Heat-capacities at low-temperatures and entropies at

$691298.15 \mathrm{~K}$ of nesquehonite, $\mathrm{MgCO}_{3} \cdot 3 \mathrm{H}_{2} \mathrm{O}$, and hydromagnesite, Am. Mineral., 57 (1972)

$692 \quad 1768-1781$. 
693 [62] A.L. Harrison, V. Mavromatis, E.H. Oelkers, P. Benezeth, Solubility of the hydrated Mg-

694 carbonates nesquehonite and dypingite from 5 to $35^{\circ} \mathrm{C}$ : Implications for $\mathrm{CO}_{2}$ storage and the 695 relative stability of Mg-carbonates, Chem. Geol., 504 (2019) 123-135.

696 [63] Q. Gautier, P. Benezeth, V. Mavromatis, J. Schott, Hydromagnesite solubility product 697 and growth kinetics in aqueous solution from 25 to $75^{\circ} \mathrm{C}$, Geochim. Cosmochim. Acta, 138 $698 \quad(2014) 1-20$.

699 [64] G. Raade, Dypingite, a new hydrous basic carbonate of magnesium, from Norway, Am. $700 \quad$ Mineral., 55 (1970) 1457-1465.

701 [65] J.H. Canterford, G. Tsambourakis, B. Lambert, Some observations on the properties of 702 dypingite, $\mathrm{Mg}_{5}\left(\mathrm{CO}_{3}\right)_{4}(\mathrm{OH})_{2} \cdot 5 \mathrm{H}_{2} \mathrm{O}$, and related minerals, Mineral. Mag., 48 (1984) 437-442. 703 [66] P. Kristova, L.J. Hopkinson, K.J. Rutt, H.M.A. Hunter, G. Cressey, Carbonate mineral 704 paragenesis and reaction kinetics in the system $\mathrm{MgO}-\mathrm{CaO}-\mathrm{CO}_{2}-\mathrm{H}_{2} \mathrm{O}$ in presence of chloride 705 or nitrate ions at near surface ambient temperatures, Appl. Geochem., 50 (2014) 16-24.

706 [67] C. Unluer, A. Al-Tabbaa, Characterization of light and heavy hydrated magnesium 707 carbonates using thermal analysis, J. Therm. Anal. Calorim., 115 (2014) 595-607.

708 [68] V. Rheinheimer, C. Unluer, J.W. Liu, S.Q. Ruan, J.S. Pan, P.J.M. Monteiro, XPS study 709 on the stability and transformation of hydrate and carbonate phases within $\mathrm{MgO}$ systems, 710 Materials, 10 (2017).

711 [69] F. Winnefeld, A. Schöler, B. Lothenbach, Sample preparation, in: K. Scrivener, R.

712 Snellings, B. Lothenbach (Eds.) A Practical Guide to Microstructural Analysis of

713 Cementitious Materials, CRC Press, Boca Raton (FL, USA), London (UK) and New York 714 (NY, USA), 2016, pp. 1-35.

715 [70] B. Lothenbach, P. Durdziński, K. De Weerdt, Thermogravimetric analysis, in: K. 716 Scrivener, R. Snellings, B. Lothenbach (Eds.) A Practical Guide to Microstructural Analysis 717 of Cementitious Materials, CRC Press, Boca Raton (FL, USA), London (UK) and New York 718 (NY, USA), 2016, pp. 177-211. 
[71] R. Snellings, J. Chwast, O. Cizer, N. De Belie, Y. Dhandapani, P. Durdzinski, J. Elsen, J.

Haufe, D. Hooton, C. Patapy, M. Santhanam, K. Scrivener, D. Snoeck, L. Steger, T. Sui, A.

Vollpracht, F. Winnefeld, B. Lothenbach, Report of TC 238-SCM: hydration stoppage

methods for phase assemblage studies of blended cements-results of a round robin test, Mater.

Struct., 51 (2018).

[72] R. Snellings, J. Chwast, O. Cizer, N. De Belie, Y. Dhandapani, P. Durdzinski, J. Elsen, J.

Haufe, D. Hooton, C. Patapy, M. Santhanam, K. Scrivener, D. Snoeck, L. Steger, T. Sui, A.

hydration stoppage by solvent exchange for the study of hydrate assemblages, Mater. Struct., $51(2018)$

[73] J.J. Thomas, S. Musso, I. Prestini, Kinetics and activation energy of magnesium oxide hydration, J. Am. Ceram. Soc., 97 (2014) 275-282.

[74] C. De Vito, L. Medeghini, S. Mignardi, F. Leccese, Synthesis of amorphous Mgcarbonates for the application in the production of advanced materials, 5th IEEE International Workshop on Metrology for AeroSpace (MetroAeroSpace), June 20-22, 2018, Rome, Italy, 446-450.

[75] S. Mignardi, C. De Vito, V. Ferrini, R.F. Martin, The efficiency of CO2 sequestration via carbonate mineralization with simulated wastewaters of high salinity, J. Hazard. Mater., 191 (2011) 49-55.

[76] R.L. Frost, S. Bahfenne, J. Graham, W.N. Martens, Thermal stability of artinite, dypingite and brugnatellite - Implications for the geosequestration of green house gases,

740 Thermochim. Acta, 475 (2008) 39-43.

741 [77] L.A. Hollingbery, T.R. Hull, The thermal decomposition of huntite and hydromagnesiteA review, Thermochim. Acta, 509 (2010) 1-11.

743 [78] T.S. Duffy, C. Meade, Y.W. Fei, H.K. Mao, R.J. Hemley, High-pressure phase-transition

744 in brucite, $\mathrm{Mg}(\mathrm{OH})$, Am. Mineral., 80 (1995) 222-230. 
745 [79] R.L. Frost, S. Bahfenne, J. Graham, Raman spectroscopic study of the magnesium-

746 carbonate minerals - artinite and dypingite, J. Raman Spectrosc., 40 (2009) 855-860.

747 [80] F. Winnefeld, S. Becker, J. Pakusch, T. Götz, Effects of the molecular architecture of

748 comb-shaped superplasticizers on their performance in cementitious systems, Cem. Concr.

749 Compos., 29 (2007) 251-262.

750 [81] J. Cheung, A. Jeknavorian, L. Roberts, D. Silva, Impact of admixtures on the hydration 751 kinetics of Portland cement, Cem. Concr. Res., 41 (2011) 1289-1309.

752 [82] D. Marchon, F. Boscaro, R.J. Flatt, First steps to the molecular structure optimization of 753 polycarboxylate ether superplasticizers: Mastering fluidity and retardation, Cem. Concr. Res., $754 \quad 115(2019)$ 116-123.

755

756 


\section{Appendix}

758 For measurement of flexural and compressive strength of $\mathrm{MgO}$ blended with hydromagnesite

759 (70/30 by mass) a technical magnesium oxide (MgO-t) was used instead of the pure one

760 calcined from brucite. The technical product is a reactive $\mathrm{MgO}$ calcined at low temperatures

761 and contains approximately 83 mass- $\%$ of $\mathrm{MgO}$ as determined by X-ray diffraction. Its

762 reactivity measured according to [50] is somewhat lower than for the pure $\mathrm{MgO}$

763 (neutralization time of $200 \mathrm{~s}$ compared to $145 \mathrm{~s}$ for the pure $\mathrm{MgO}$ ), but still in the range of

764 medium reactivity. Fig. A1 shows that the particle size distribution of the technical $\mathrm{MgO}$ is

765 significantly coarser than the one of the pure $\mathrm{MgO}$.

766
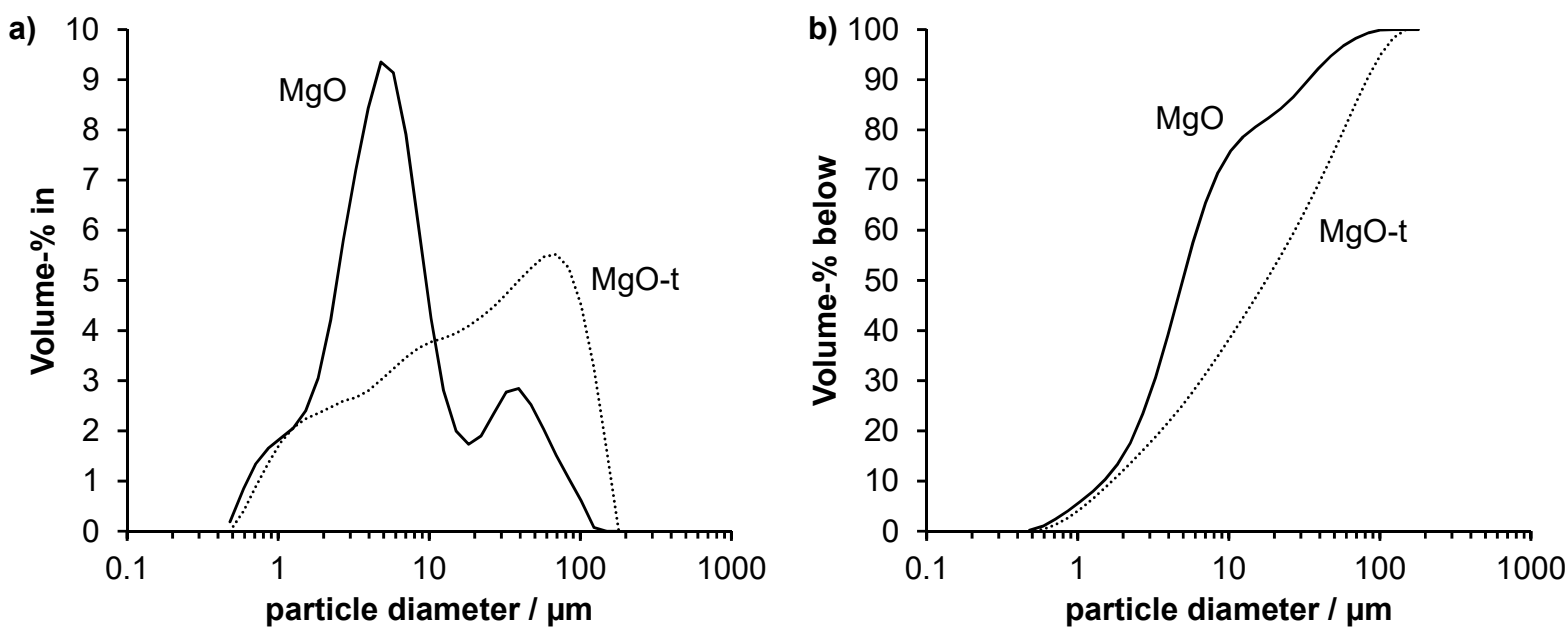

767 Fig. A1: Particle size distribution of pure $\mathrm{MgO}$ and technical $\mathrm{MgO}$ (MgO-t). (a) differential

768 particle size distribution, (b) cumulative particle size distribution.

770 Mortars of MgO-t blended with hydromagnesite ( $70 / 30$ by mass) were prepared according to

771 EN 196-1, except that higher water/binder ratios and smaller prisms $(25 \mathrm{~mm} \times 25 \mathrm{~mm} \times 100$

$772 \mathrm{~mm}$, 9-fold mould) were produced. Table A1 gives the mix designs. Three different water/binder $(\mathrm{w} / \mathrm{b})$ ratios of $1.20,0.95$ and 0.70 were used. Workability of mixtures with $\mathrm{w} / \mathrm{b}$

774 ratios of 0.95 and 0.70 was adjusted by adding a commercial superplasticizer based on

775 polycarboxylate ether. 
777 Table A1: Mix designs of the mortars used in this study referring to $100 \mathrm{~g}$ binder.

\begin{tabular}{ccccccc}
\hline $\mathrm{MgO}-\mathrm{t}$ & $\mathrm{HY}$ & Water & $\begin{array}{c}\text { Super- } \\
\left.\text { plasticizer }^{1}\right)\end{array}$ & $\begin{array}{c}\text { Sand }^{2} \text { ) } \\
0-0.5 \mathrm{~mm}\end{array}$ & $\begin{array}{c}\text { Sand }^{2} \text { ) } \\
0.5-1 \mathrm{~mm}\end{array}$ & $\begin{array}{c}\text { Sand }^{2} \text { ) } \\
1-2 \mathrm{~mm}\end{array}$ \\
$\mathrm{~g}$ & $\mathrm{~g}$ & $\mathrm{~g}$ & $\mathrm{~g}$ & $\mathrm{~g}$ & $\mathrm{~g}$ & $\mathrm{~g}$ \\
\hline 70 & 30 & 120 & - & 100 & 100 & 100 \\
70 & 30 & 95 & 1.5 & 100 & 100 & 100 \\
70 & 30 & 70 & 3.0 & 100 & 100 & 100 \\
\hline
\end{tabular}

778

779

780

781

782

783

784

785

786

787

788

789

790

791

792

793

794

${ }^{1}$ ) A commercial superplasticizer based on polycarboxylate ether (solid content 40 mass-\%) was used. The dosage refers to the product as delivered.

${ }^{2}$ ) Obtained by sieving EN 196-1 standard sand.

Flexural and compressive strength were tested after 1, 3, 7 and 28 days on 2 prisms each.

Flexural strength was measured using a span of $75 \mathrm{~mm}$ and a load rate of $0.02 \mathrm{kN} / \mathrm{s}$, while for compressive strength a load rate of $0.3125 \mathrm{kN} / \mathrm{s}$ was used.

Fig. A2 shows the results for flexural and compressive strength. As expected, flexural strength and compressive strength increase with decreasing w/b. For w/b $=0.70$ a quite acceptable compressive strength of $21 \mathrm{MPa}$ after 28 days is reached, which could be further optimized by lowering the $\mathrm{w} / \mathrm{b}$ ratio to $0.5-0.6$.

The results also suggest that the used superplasticizer does not lead to strong retardation despite the high dosage used, which is confirmed by isothermal calorimetry (Fig. A3). This behavior towards superplasticizers is quite different to the one of Portland cement, where such high dosages would cause a strong retardation [80-82]. 

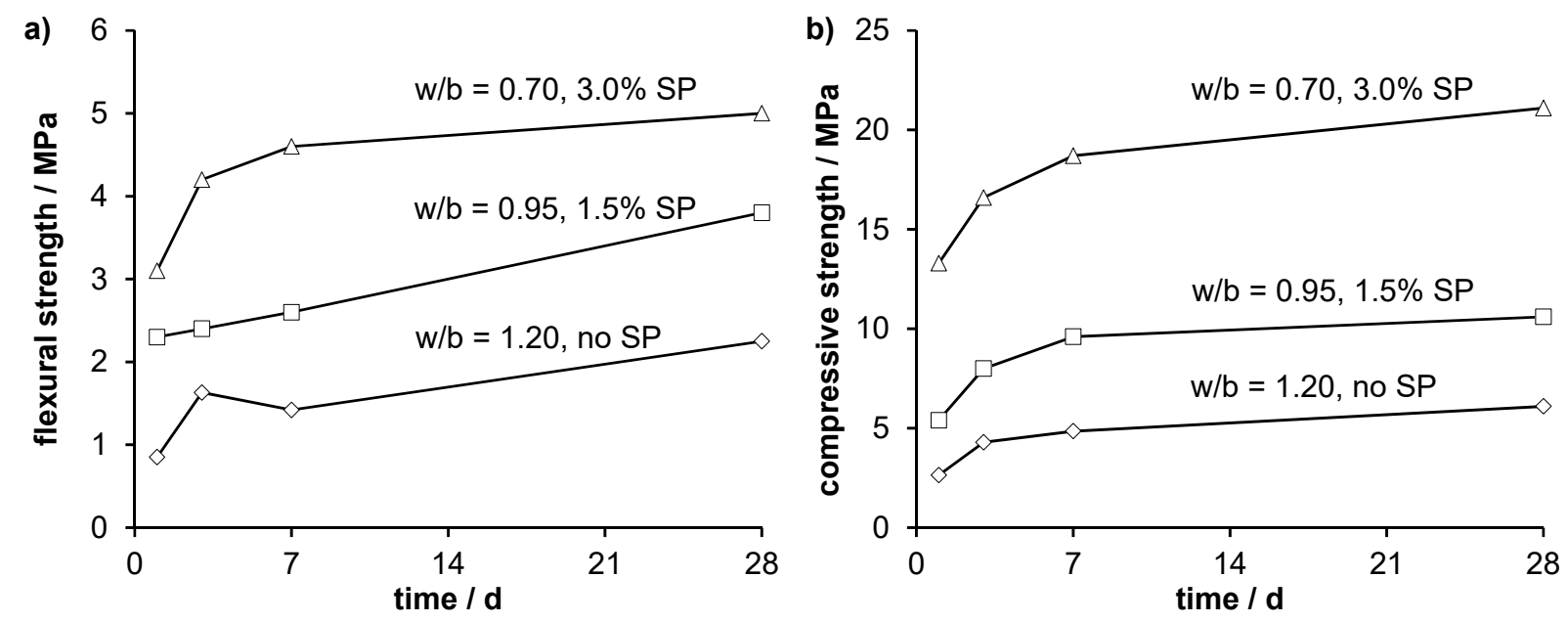

795 Fig. A2: a) Flexural and b) compressive strength of mortars with binder MgO-t/HY 70/30

796 using different water/binder ratios and superplasticizer (SP) amounts. Maximum standard

797 deviations are $12.5 \%$ for flexural strength and $6.6 \%$ for compressive strength.

798

799
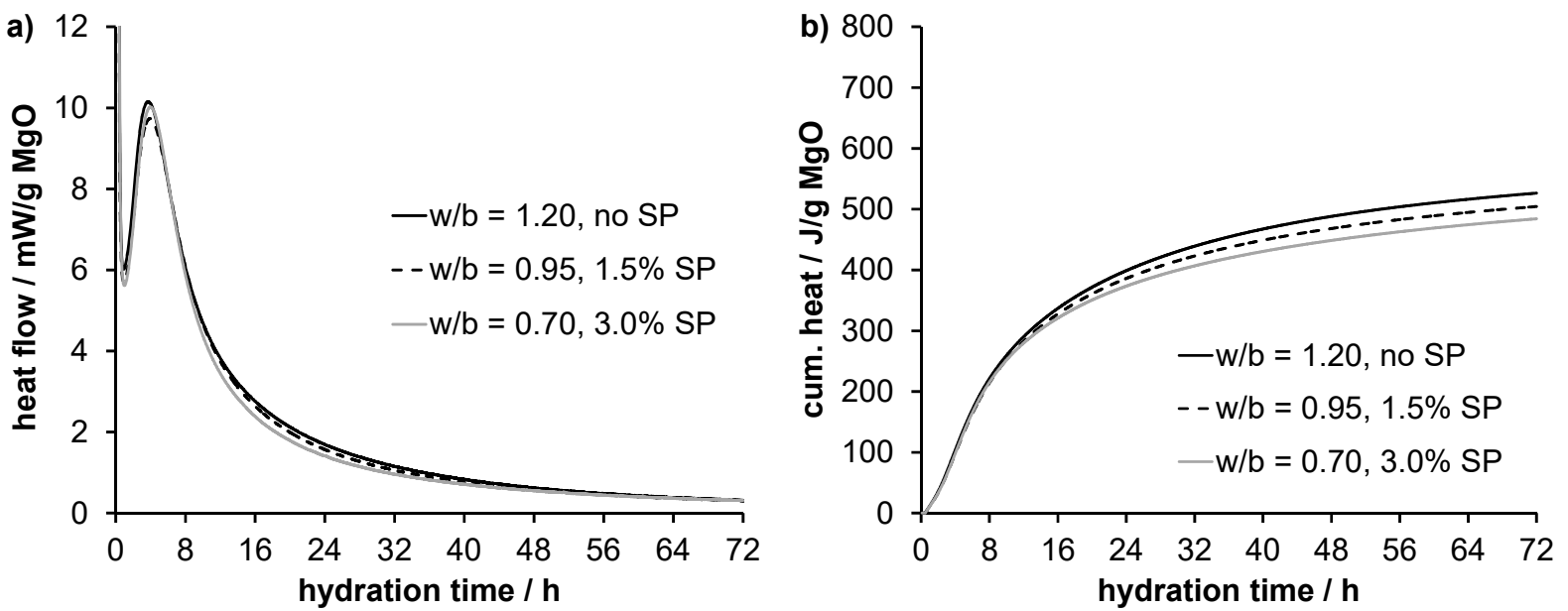

800 Fig. A3: Isothermal heat flow calorimetry of $\mathrm{MgO}-\mathrm{t} / \mathrm{HY} 70 / 30$ hydrated using different

801 water/binder ratios and superplasticizer (SP) amounts; a) heat flow, and b) cumulative heat. 